\title{
Using digital devices to help people lose weight: a systematic review
}

\section{Madeleine Besson}

Sayfood, INRAE, Paris-Saclay University, Versailles France and AgroParisTech, Massy, France

\section{Patricia Gurviez}

Département of SESG, UMR 782 Sayfood (Université Paris-Saclay, INRAE, AgroParisTech), Versailles France and AgroParisTech, Massy, France, and

\section{Julia Carins}

Social Marketing@ Griffith, Griffith Business School, Griffith University, Queensland, Australia

\begin{abstract}
Purpose - When fighting the burden of overweight and obesity, diet remains a powerful preventive factor. The purpose of this paper is to stimulate more efficient interventions on diet change by synthesising knowledge of previous weight loss programmes based on the use of digital devices.

Design/methodology/approach - Following the preferred reporting items for systematic reviews and meta-analyses approach, a systematic literature review through five databases was undertaken focussed on the assessment of studies oriented towards diet change that incorporated digital devices including computers, tablets, mobile phones, portable and nonportable tracking devices. In total, 15 empirical studies (2004-2018) were identified and examined for efficacy and presence of theory and behaviour change techniques.

Findings - Digital devices supporting weight loss programmes have evolved rapidly over the past 15 years, from reminders using the short message system to self-quantification through mobile applications. Nine studies show a significant difference between conditions, in favour or one (or more) intervention arm. The remaining studies failed to find significance between conditions but were using a comparison with an active intervention, potentially indicating equivalent efficacy. A low level of theory use and use of behavioural techniques was evident. Research limitations/implications - The literature review is limited to studies that have scientifically evaluated the (potential) weight loss associated with the weight loss intervention. This review could be put into perspective with other complementary research, in particular,
\end{abstract}


qualitative research aimed at exploring participants' motivations to use (or not) digital devices to lose weight.

Social implications - Given their low cost and the size of the overweight population, it appears that public health policies could integrate digital devices more strongly in their efforts to combat obesity. Social marketing can add its expertise to medical-based programmes which in return bring their need for more quantitative evaluation of the efficacy of the interventions.

Originality/value - Few previous reviews have examined the extent of the efficiency in digital diet change programmes. The review shows that, in general, digital interventions can support weight loss for adults; however, more studies are required to provide a strong evidence base for efficacy. Given their low cost and the size of the overweight population, public health policies could integrate these devices more strongly in their efforts to combat obesity. A theorydriven social marketing perspective could enhance development ensuring interventions are effective and valued by users.

Keywords Public health, Obesity, Social marketing, Programme, Digital intervention, Systematic literature review

Paper type Literature review 


\section{Using digital devices to help people lose weight: a systematic review}

\section{Introduction}

\section{Background}

The negative consequences of the global obesity epidemic are now well known [WHO (World Health Organization) 2018]. In 2015, being grossly overweight or obese contributed to 4 million deaths globally, which represented $7.1 \%$ of the deaths from any cause (GBD 2015 Obesity Collaborators, 2017). Obesity and overweight are risk factors for an expanding set of severe chronic diseases. Furthermore, they contribute to economic and social harms as well as the difficulties experienced by overweight and obese people in their lives, such as discrimination associated with overweight across many life domains, such as the workplace, interpersonal relationships or transportation (Puhl et al., 2015).

Nevertheless, overweight and obesity often are preventable and can be reversible, mainly by changing and maintaining diet and physical activity behaviours that support attainment of a healthy weight. Social marketing is widely recognised as a credible behaviour change discipline (Rundle-Thiele, 2015), which has been used successfully to alleviate many health issues. This includes efforts to increase preventive behaviours such as healthy eating and physical activity (Carins and Rundle-Thiele, 2014; Gordon et al., 2006; Truong, 2014; Xia et al., 2016). Social marketing aims to change behaviour to bring about individual and societal benefit, and although this aim is shared with many other behaviour change approaches, the strength that social marketing brings to the space comes from the marketing lens - a focus on delivering solutions that are valued by people (French and Russell-Bennett, 2015).

Social marketing is a dynamic and evolving field (French and Russell-Bennett, 2015), which continues to pursue innovation to enhance the delivery and effectiveness of its programmes ${ }^{1}$ (Kubacki and Rundle-Thiele, 2017; Rundle-Thiele et al., 2019; Wymer, 2011). This involves consideration of new technologies that have the potential to be effective and acknowledgement that programmes need to be delivered through modes that are aligned with contemporary daily life. Today's society has been characterised as the digital era, with almost universal daily use of digital technology. Incorporating digital technologies into social marketing programmes offer effective ways to increase reach and engagement, delivering similar outcomes more costeffectively (Cugelman et al., 2011). The use of digital technologies to engage people in weight loss have many advantages for social marketers, including increasing customisation to better

\footnotetext{
${ }^{1}$ In this paper, we use the terms "program" and "intervention" interchangeably
} 
meet citizen's needs (citizen orientation), ensuring efficient delivery of targeted strategies to different groups (segmentation), delivering solutions at the right time and place (value proposition delivery) and quantifying one's efforts and results (behavioural goals) (Mehmet et al., 2020; Dibb, 2017). These advantages assist social marketers to more effectively design and deliver programmes that continue to be aligned to the principles of social marketing (Andreasen, 2002; ESMA, 2017).

Digital devices have been used for weight management, including weight loss, since the end of the 20th century. This includes use in both nutritional public health settings and a rapidly growing market of commercial applications ${ }^{2}$ available on smartphones since 2010 . However, prior to building digital social marketing programmes, or social marketing programmes containing digital elements, there is a need to assess the efficiency of any digital programmes focussed on weight loss that have already been developed. Systematic reviews are a useful tool to assess what has been done, what works and what does not, to strengthen the means of fighting the obesity epidemic for public authorities. Previous reviews have begun to examine the use of digital technologies in social marketing, or more generally health behaviour change. Kubacki et al. (2015) investigated social marketing interventions using digital technologies, finding few implemented social marketing to its fullest extent. Their review included interventions for any behaviour and found only one intervention focussed on healthy eating. Their review stopped short of examining the effectiveness of those interventions, remaining focussed on how comprehensively social marketing could be deployed through a digital medium. A systematic review of eHealth interventions for weight management for young adults discovered a limited evidence base and mixed findings for effectiveness with fewer than half of the interventions producing a positive outcome (Willmott et al., 2019b). This review identified self-regulation, feedback and contact with an interventionist, social support, and behavioural prompts were more commonly present in effective interventions. A similar review of eHealth interventions for young adults across many health behaviours, found some effect in the short-term, but insufficient evidence in the longer-term (Oosterveen et al., 2017). A metaanalysis of Webbased weight loss interventions for adults, also found greater short-term but not long-term weight loss than offline interventions (Beleigoli et al., 2019). Their review acknowledged diversity among the digital interventions, which may or may not contribute to successful outcomes.

\footnotetext{
${ }^{2}$ In this paper, we use the terms application and the concise form "App" interchangeably
} 
While these reviews have provided some insights into the features and effectiveness of digital devices to support weight loss, they have either not examined effectiveness (Kubacki et al., 2015), restricted their focus to young adults (Willmott et al., 2019b; Oosterveen et al., 2017), or not attempted to determine which features of diverse digital interventions are likely to contribute to success. This review sought to address some of these gaps, by examining the effectiveness of digital weight loss interventions for adults and the digital features that may contribute to successful behaviour change. This knowledge may help public authorities to develop social marketing interventions with and for adults to assist them to achieve and maintain a healthy weight.

Diet remains a key determinant of obesity although not the only factor involved (Hawkes et al., 2015). While numerous behavioural changes may be required to achieve and maintain a healthy weight, social marketing principles emphasise the setting of specific behavioural goals (ESMA, 2017), which may then necessitate development of different strategies for different behaviours, to be deployed concurrently or sequentially. According to some authors (Gill et al., 2005; Willmott et al., 2019b), prevention is easier than cure when fighting the burden of overweight and obesity, and diet remains a preventive or protective factor. We therefore intend to focus on the assessment of publications mainly oriented towards a diet change.

Technology has become a cost-effective means of engaging people in losing weight (Krukowski et al., 2011) and an integral part of daily life. In this systematic literature review (SLR), we first sought to identify digital interventions that encourage weight loss, based on dietary change and sometimes accompanied by physical activity recommendations. To ensure we were reviewing robust evaluations of effectiveness, we sought evaluations that included a comparison group in the design. We sought to compare the effectiveness of the digital interventions and then examined the different devices and features used, as well as the theoretical basis and behavioural change techniques incorporated in the weight loss programmes. Our objective was to provide knowledge that will support the development of effective and efficient interventions by incorporating theoretical and operational inputs that have been used effectively in previously delivered digital programmes.

\section{Method}

\section{Search strategy}

Using systematic review procedures, the literature was reviewed to examine healthy eating interventions coupled with digital devices over a 15-year period (2004-2018). Five databases (PubMed, Web of Science, Business Source Complete, EBSCO e-journals and ScienceDirect) 
and Google Scholar were searched using a combination of terms (diet* or healthy eating or weight* AND connected devices or SMS or App* or Web* AND intervention or campaign or programme). Backward searching from reference lists and previous SLRs and forward searching using author and study names were conducted to find other articles related to the studies discovered by the search.

\section{Screening strategy}

After duplicates were removed, the records were assessed for eligibility by two independent reviewers. When the same cohort had been used for multiple publications, the study presenting the results on the longest period was chosen. The full text of the remaining articles was then retrieved for further examination. At each stage, every disagreement was discussed and resolved between analysts.

\section{Eligibility criteria}

The eligibility criteria used in this review are as follows:

- $\quad$ articles had to be peer-reviewed;

- in English;

- studies should be conducted among adult populations (not defined subpopulations, for example, mothers of young children);

- include participants who were free from other acute illnesses or chronic disease ${ }^{3}$,

- be empirical studies and not theoretical research or literature reviews; and

- provide quantitative measures relating to weight loss or weight loss maintenance.

In this systematic review, digital devices used to change behaviours included computers, tablets, mobile phones and portable and non-portable tracking devices. For studies to be selected in our review, digital devices needed to be the primary means of intervention delivery in at least one treatment group.

Studies were excluded based on the following criteria:

- not peer-reviewed;

\footnotetext{
${ }^{3}$ Treatment for some pathologies lead to medication-induced weight gain (Domecq, Prutsky et al., 2015), which may render dietary behavior change ineffective. As a result, we focused on overweight people who do not have any other medical problems.
} 
- not in English;

- conducted on specific subpopulations;

- included participants who were not healthy and free from acute illness or chronic disease;

- not empirical; and

- did not provide quantitative measures relating to weight loss or weight loss maintenance.

The number of excluded records, and reasons for exclusions, are reported in Figure 1.

\section{Flowchart of the literature search process}

Data extraction and management. A data extraction form based on the PRISMA ${ }^{4}$ declaration was developed to extract the characteristics of the study (Liberati et al., 2009). The data extracted included the following: details of the study (author, year of publication and country), study design, participants (sample size, characteristics and retention rate), details of the intervention and duration of the study, measurements, results and conclusions. Next, the authors thoroughly and independently reviewed the studies and resulting summary tables to determine their accuracy and relevance. All inconsistencies were resolved through discussion.

\section{Sample of articles}

As the primary objective of this review was to assess the efficiency of programmes that used digital devices to help people lose weight, our review focussed on studies that reported a quantitative assessment of the outcomes on weight loss. The selection of studies evaluating weight loss efficacy from 2004 to 2018 resulted in a sample of 15 articles, with all the selected articles reported in medical or health journals. To ensure our search had not missed digital social marketing interventions, were checked three other systematic reviews of similar scope. Carins and Rundle-Thiele (2014) examined 32 empirical interventions on eating behaviour between 2000 and 2012 that were classified as social marketing by intervention authors (Carins and Rundle-Thiele, 2014). All 32 studies were outside the scope of this review: only 6 targeted adults, the remainder focussed on the elderly, children and college students. Of the six studies, only one referred to an online information intervention, with the only measure of that intervention being response rate to the campaign (Tettey, 2011). The review covered the period 2000-2012 which could explain the scarcity of studies using digital devices. Indeed, apart from

\footnotetext{
${ }^{4}$ PRISMA: Preferred Reporting Items for Systematic reviews and Meta-Analyses
} 
experimental devices developed and tested in the medical field, the main digital devices used by consumers and observed by marketing researchers are smartphones, which have been in widespread use since 2010, which overlaps with the latter end of the Carins and Rundle-Thiele review (2014). We also examined the studies captured in the Kubacki et al. (2015) review of social marketing interventions using digital technologies finding no nutrition or weight loss interventions. More recently, in their systematic review, Shawky et al. (2019) found four social marketing programmes that aimed to change dietary behaviour using social media (Shawky et al., 2019). However, their review focussed on social media and did not meet our inclusion criteria regarding what was measured or who was targeted.

\section{Data synthesis}

The empirical studies were analysed to determine whether the authors presented evidence of weight loss or sustained weight loss for any programme that included digital devices. It was soon evident that the studies varied greatly in the design used and the quantitative measures used, so a narrative approach to data analysis was used in this review. For systematic reviews to include quantitative meta-analyses to assess the extent of change in outcomes across primary studies and to analyse the sources of variation between study results, summary studies must be accompanied by appropriate quantitative data (Gurevitch et al., 2018). With only 15 studies extracted from our systematic research, a meta-regression would not have the power to reliably detect modest associations (Hempel et al., 2013). In addition, a large degree of heterogeneity was apparent within the 15 studies (in terms of number of participants, experimental conditions, duration of the experiment and so on), making it impossible to calculate an effect size for a particular outcome. In such cases, it is considered more appropriate to undertake a systematic narrative review rather than a meta-analysis (Liberati et al., 2009). Systematic narrative reviews are useful for exploring the development of specific ideas to advance our knowledge of a particular field of research (Gurevitch et al., 2018).

Our narrative synthesis includes two aspects:

(1) intervention results in terms of weight loss; and

(2) digital components/features used, theoretical support and behavioural change techniques embedded within the interventions.

To facilitate the second aspect, we examined each intervention for the presence of theory and behaviour change techniques. Beyond noting if the authors referenced a theoretical framework, we analysed the level of use of theory they had based on the work of Michie and Prestwich (2010). The latter suggest calculating a theoretical score by checking if reference is made to: 
- underpinning theory;

- targeting of relevant theoretical constructs;

- use of theory to select recipients or tailor interventions;

- measurement of theoretical constructs;

- testing of mediation effects; and

- refining theory.

This calculation has previously been used to identify the theoretical support within studies included in a systematic review (Webb et al., 2010; Garnett et al., 2018; Wilmott et al., 2019a). Using the Michie and Prestwich coding scheme (2010), two independent researchers calculated the theoretical score for each study to ensure the reliability of coding; with discrepancies solved through discussion. We also examined the studies to look for evidence of the 40 behaviour change techniques specified by Michie et al. (2011a, 2011b). Study descriptions were not detailed enough to determine if some techniques were included in the intervention - but those that were described were recorded against each study.

\section{Results}

\section{Description of the included studies}

The 15 studies included in our review report statistically reliable results of digitally delivered or digitally supported weight loss programmes. All studies were published in medical and health journals. The participants were overweight adults (mean size of the sample: 142 participants $(\mathrm{SD}=110.4)$ participating in studies for a mean duration of 32 weeks $(\mathrm{SD}=25.6)$. Most studies were conducted in the USA, with one in Australia, one in Korea, one in Belgium and one in Finland.

Because of the rapid evolution of information technologies, the studies used various devices and various interaction software. Over the years the interventions moved from prompt messages (SMS, or short message service) on mobile phones or development of specific websites for interventions, to the use of mobile applications (apps), which corresponds to recent consumer practices. Devices used include personal computers (PC) (in six studies published between 2004 and 2012), mobile phones or smartphones (11 studies) and a personal digital assistant (PDA) (one study); two studies used both PCs and mobile phones. Interactions with the participants were managed through websites (six studies between 2004 and 2012), specific software for the PDA study (Burke et al., 2011), SMS (five studies between 2009 and 2013), social networks (Turner-McGrievy and Tate, 2011; Napolitano et al., 2013) or mobile 
applications (apps) (six studies between 2010 and 2018). Earlier studies analysed both the acceptability of the connected programmes and their efficacy (Campbell et al., 1994), whereas the most recent studies no longer determined the acceptability of technologies and just focussed on evaluating the effect on weight loss.

Each study was intrinsically interesting, but the specificities of each study did not allow a direct comparison between them. As presented in Table 1, the profiles of participants were variable, as were the technologies tested in the various studies and the duration of the studies.

To provide useful information to improve the design of future interventions, the authors sought to provide two narratives, one relating to the lessons of the studies derived from examination of the effectiveness of the digital interventions and the second analysing the delivery features, theoretical support and behavioural techniques embedded within the interventions. These narratives underpinned some recommendations for future research.

\section{Overall effectiveness of interventions using digital devices for weight loss}

The effectiveness of digital interventions aimed at weight loss was evaluated and then consideration given to the use of theory, behaviour change techniques and other elements of the intervention (e.g. monitoring, feedback or social support) within the intervention. In general, the studies indicate that digital interventions can support weight loss for adults, with nine studies showing a significant difference between treatments, in favour of one (or more) intervention arm (Tate et al., 2006; Haapala et al., 2009; Shaw et al., 2013; HarveyBerino et al., 2010; Patrick et al., 2009; Lee et al., 2010; Brindal et al., 2018; Napolitano et al., 2013; Hurkmans et al., 2018). The remaining six studies failed to find a significance difference between treatments but had used an active intervention as a comparison (for example, an inperson or paper-based intervention), meaning it was possible that the digital intervention was as successful as the intervention used as the comparison (Brindal et al., 2018; Shapiro et al., 2012; Burke et al., 2011; Turner-McGrievy and Tate, 2011; Womble et al., 2004; Svetkey et al., 2015).

Digital devices were shown to support weight loss for overweight adults through automated counselling (Tate et al., 2006), web programmes including personalised interactions (Haapala et al., 2009; Shaw et al., 2013), internet chats (Harvey-Berino et al., 2010), personalised text messages (Patrick et al., 2009), mobile apps (Hurkmans et al., 2018; Lee et al., 2010; Brindal et al., 2018) or podcast interventions (Turner-McGrievy and Tate, 2011). Napolitano et al. (2013) failed to demonstrate the efficacy of a weight-loss intervention on Facebook targeting young adults (college students); however, another treatment arm using the same Facebook 
intervention combined with SMS prompts, feedback and social support was found to be effective.

When comparing the efficacy of digital intervention to traditional face-to-face/human counselling interventions, the results were found to be mixed. Whereas most technological devices were shown to be relatively effective at helping with weight loss, some programmes using a digital device were ineffective or comparably effective to traditional interventions. Hurkmans et al. (2018) found a hybrid (digital and human) intervention to be more effective than digital-only or human-only interventions, whereas Svetkey et al. (2015) found no difference among an app, human coaching and information provision (control). HarveyBerino et al. (2010) found in-person delivery more effective than internet and hybrid delivery; and Tate et al. (2006) found that automated counselling was similar to human counselling in the short term, but human counselling was more effective in the longer term. This finding is consistent with Mohr et al. (2011) who proposed that adherence and effectiveness of e-Health interventions based on digital devices are greatly increased when human intervention is integrated into the intervention.

Devices have evolved over time; however, no study in this review attempted to compare the same programme in different technological settings (app versus website, etc.). It appeared that one technology replaced another technology and that over time the studies were trying to validate a new digital technology, interface or protocol. Some studies attempted to measure the additional effectiveness of a multi-technology device. However, neither the adding of text messages to a website (Shapiro et al., 2012) nor using Twitter in combination with a podcast programme (Turner-McGrievy and Tate, 2011) were found to increase the efficiency of the original digital intervention.

The mixed results above may be related to different theoretical approaches or underpinning as suggested by Webb et al. (2010). Theoretical insights remain paramount to understand the complexity of consumer behavioural changes (Hekler et al., 2016; Willmott et al., 2019b). Furthermore, Angus et al. (2013) suggest that interventions should be based on solid theories, and theory should also form the basis for evaluation. In the following paragraphs, we analyse the theoretical support of the studies, identifying the theory(s) mentioned and the level of use of the theoretical framework.

\section{Behaviour change theories supporting digital interventions}

In eight of the 15 studies, the published article mentioned that a theoretical framework was used to develop the weight loss programme (Table 2). This represents around half of the 
studies; however, it does not necessarily indicate an absence of theory in any of the other studies - it may be that the authors did not explicitly report it in the article.

Table 2 presents the theories reported in the articles in the review, the level of use of the theoretical framework (as reported) and a simplified statement of the results of each research project on the effectiveness of the weight loss devices tested. The last two columns present, respectively, the result of each treatment intervention ("WL observed": weight loss for one specific treatment) and the possible difference between the interventions ("Treatment differences). "No treatment difference" means that no statistically significant difference appears between the two (or three) treatments. When a difference appears between some of the treatments, this is described in detail.

Of those weight loss interventions that clearly mentioned a theoretical reference, five were based on Bandura's Social Cognitive Theory or self-efficacy theory (Bandura, 1976; Bandura, 1986; Bandura, 1998). Other theoretical frameworks include a self-regulation model and systems contingency approach, both also based on Bandura's work; the theory of planned behaviour (Ajzen, 1991) and the regulatory focus theory (Higgins, 1998). In our sample, studies claiming a theoretical framework did not show more positive results than studies that did not mention any framework.

When examining how well theory was embedded within each intervention, the vast majority of studies obtained an average score (between 10 and 16), compared to the maximum score of 28. Most studies focus on the effectiveness of new technologies without relating theory and technologies, which may explain why they do not reach a "strong" level of theory".

Research articles that referred to a theory often stated it was used as the framework to develop the intervention but did not state how it was used. Svetkey et al. $(2015: 2,134)$ report that "both interventions were designed by our research team based on Social Cognitive Theory and Transtheoretical Model; and Shapiro et al. (2012:413) just state that "the theoretical foundation (of the intervention) was social cognitive theory". However, the vast majority of the studies did not report testing the theory or any of the variables highlighted in the theory. The exception was Shaw et al. (2013) who offered contributions based on the specific testing of theoretical variables on the behaviour of participants. Shaw et al. (2013) tested the effectiveness of text messages based on the Regulatory focus theory finding interventions based on the variables of focus within the theory (promotion and prevention) were more effective than neutral messages (Shaw et al., 2013).

\footnotetext{
${ }^{5}$ The detailed calculation of theoretical level scores is available from the authors
} 


\section{Behaviour change techniques supporting digital interventions}

As social scientists have pointed out, interventions to change behaviour are complex and involve various interacting components. Over time, psychology researchers have identified successful behaviour change techniques and researchers have proposed a list and taxonomy based on expert evaluations (Abraham and Michie, 2008; Michie et al., 2013). Behaviour change techniques are defined as observable, replicable and irreducible components of an intervention designed to alter or redirect causal processes that regulate behaviour (Michie et al., 2011a, 2011b). The articles did not contain sufficient detail to determine if some behaviour change techniques (BCTs) were used, or to determine discriminate between similar BCTs (for example, the first four BCTs in Michie's 2011 taxonomy concern information provision - of four different types of information). The behaviour change techniques used in the studies in this review (as reported in the articles) included, in at least one intervention arm: information (all 15 studies); self-monitoring (15 studies); feedback, (10 studies); social support (9 studies); goal setting (7 studies); prompts ( 7 studies); action planning or task setting (6 studies); rewards (2 studies) problem-solving and relapse prevention (2 studies). While this review does not attempt to establish the efficacy of BCTs (that has been established elsewhere), there are observations that can be made in reference to the use of some BCTs within a digital platform. The most commonly used BCTs are discussed in this light in the paragraphs below.

\section{Traditional versus online monitoring}

Self-monitoring of behaviour has been shown to be an effective technique to support behaviour change (Michie et al., 2011a, 2011b), and traditional weight loss programmes are based, to varying degrees, on individual coaching and remote self-assessment of participants' eating behaviour. This self-assessment, traditionally carried out on paper forms returned to the programme organisers, can be replaced by the participant entering the information on digital devices, moving from remote reporting on paper to remote online reporting. All studies in this review involved self-monitoring in one or more intervention arms. Self-monitoring was included in the intervention arm(s) that were found to be effective compared to information only comparisons (Patrick et al., 2009) or no treatment controls (Haapala et al., 2009; Lee et al., 2010) and also in studies finding no difference between interventions and information-only comparison (Brindal et al., 2018; Shapiro et al., 2012; Svetkey et al., 2015). Most of these were interventions containing multiple BCTs. However, two studies directly analysed the impact of replacing remote reporting on paper with remote online reporting. Womble et al. (2004) 
compared a paper and pencil intervention versus a website device, Burke et al. (2011) compared a PDA intervention with a paper and pencil one; both confirmed that the digital device was as effective as the traditional paper and pencil method. Compared to the traditional paper diary recording, digital devices offered enhanced practicality, whether in the form of a website or a mobile PDA, and these studies indicated that this self-monitoring was executed just as effectively on a digital platform.

\section{Traditional versus digital feedback}

Feedback has been an essential element of theories of learning and instruction (Mory, 2004). The feedback technique is also a major instrument for changing health behaviour (Brug et al., 1998; DiClemente et al., 2001). Ten studies included feedback in one or more intervention arms. Feedback was also present in the intervention arm(s) of effective interventions (Patrick et al., 2009; Hurkmans et al., 2018) and in those found to be no different to controls (Brindal et al., 2018; Svetkey et al., 2015; Burke et al., 2011; Womble et al., 2004). Again, most of these were interventions containing multiple BCTs. Napolitano et al. (2013) compared Facebook interventions (one with information and social interaction/support, the other with feedback added alongside other BCTs) finding the enhanced Facebook intervention to be more successful than the information-based version and the no treatment control. On the other hand, Tate et al. (2006) compared digital and non-digital feedback directly in the form of automated counselling and human counselling, finding both effective, but human counselling more effective in the longer term. These studies suggest that feedback provided through a digital platform may contribute to effectiveness, but there are elements of human feedback that may not easily translate to a digital platform.

\section{Traditional versus digital social support}

Social support has been shown to play an important role in changing social norms related to obesity and enhancing weight-loss outcomes (Leahey et al., 2011; Wing and Jeffery, 1999) Today, information technologies have completely changed social networking, and social network sites are hugely successful, Facebook being an emblematic case of this phenomenon. Nine studies included feedback in one or more intervention arms. Several researchers have tried to provide social support on digital devices. Seeking to reproduce the social support provided to participants in classical weight loss programmes within a digital environment, Turner-McGrievy and Tate (2011) tested the added value of interactions on the Twitter social network. In a four-month period, this interactive method did not increase the efficacy of a 
simple podcast weight loss intervention. As mentioned above, Napolitano et al. (2013) used Facebook in a weight loss intervention for college students, finding the enhanced Facebook intervention more successful than the simpler version and the no treatment control. Within this enhanced Facebook intervention they provided a buddy for personal support, demonstrating that social support provided through digital means can contribute to success.

\section{Participant interaction with digital interventions}

Interventions delivered through digital devices have the ability to deliver high reach with low cost (Cugelman et al., 2011). However, to enable behaviour change this requires effective participant interaction. Some studies measured aspects of participant interaction. Shaw et al. (2013) measured the acceptability of a SMS delivered intervention, with users finding it useful and beneficial. Overall, participants reported favourable reactions to the digital communication medium. Lee et al. (2010) tested a gamified smartphone app, finding effective, but also finding users were satisfied with the app, reporting it was useful, easy and interesting. Importantly, Lin et al. (2018) showed that engagement increases the intervention efficacy. More specifically, engagement - measured in their study as the frequency of participants' use of various intervention components of the weight loss programme - was correlated to weight loss in the personal coaching programme and in the digital weight loss programme for the first six months. This finding is supported by other studies conducted retrospectively (Johnson and Wardle, 2011; Serrano et al., 2016). In particular, Johnson and Wardle (2011) analysed the logs of 3,621 users of a commercial weight loss application; they show that engagement is positively correlated to declared weight loss.

\section{Discussion}

Social marketing, as a constantly evolving field of research and application, regularly adopts and integrates new technology into practice. Digital technology has become part of everyday life and has been incorporated into social marketing programmes across a number of behavioural contexts. This systematic review aimed to examine whether interventions delivered through digital technology are effective in weight loss or weight management and then to further examine aspects of those digital interventions. The 15 studies identified in this SLR were conducted by teams of researchers from the fields of medicine, nutrition and clinical psychology, rather than specifically in social marketing. The evaluations found some evidence that digital interventions can support weight loss for adults, finding digital interventions to be 
more effective in some cases, or as effective as in other cases in comparison to interventions using traditional methods.

\section{Weight loss interventions and theoretical frameworks}

Evidence for the effectiveness of interventions based on theories of behaviour change has been emphasised by various authors (Albarracín et al., 2005; Angus et al., 2013). In this review, only half of the interventions mentioned theory, and strength of theory integration was generally low. There is a general agreement in social science on the importance of integrating a theoretical framework to evaluate the effectiveness of programmes addressing health behavioural changes. However, this review highlights a potential weakness of the medically based research on digital weight loss interventions that has been conducted to date in relation to theory testing. It appears that when working with new digital devices, researchers in the medical world do not integrate the theory any more than the developers of commercial applications (West et al., 2013). It therefore remains important for any developer of digital interventions to embed a relevant theoretical framework to increase the likelihood of behaviour change and digital devices appropriation. Equally, it is important to take medical evidence into account, which is particularly noticeable when researchers compare the effectiveness of traditional evidence-based programmes and commercial applications on smartphones. For example, when comparing a commercial website and a therapist-led programme on the internet, Gold et al. (2007) expressed concern about the poor results of the commercial programme and about the lack of consideration of the results of medical studies by commercial programme developers. Rivera and colleagues also make this point, having reviewed 393 mobile apps for weight loss and weight management, showing that these apps generally lack important evidence-based features, do not include health-care experts in their development process and have not undergone rigorous scientific testing (Rivera et al., 2016).

BCT are another important element for researchers and developers to consider in the construction of interventions. However, without a theoretical basis, even the abundant literature on behaviour change techniques may be insufficient to design an intervention for a new situation (Foy et al., 2005). The integration of behaviour change techniques is considered a positive factor for the effectiveness of health programmes; however, they should not be considered to be mere substitutes for the theories that underlie them. Some authors have noted that the inclusion of too few BCTs in digital interventions may render them ineffective, whereas too many may be confusing and counterproductive (Cugelman et al., 2011). 


\section{Limitations and future research avenues for social marketing}

The objective of our research was to provide a comprehensive assessment of the efficacy of previously developed digital programmes focussed on weight loss, to provide knowledge that may assist others when building social marketing programmes with and for overweight adults at a community or national level. This review is limited by a small pool of studies, and therefore conclusions must be treated with caution. This limited evidence base, along with the lack of digital weight loss interventions captured in other reviews (Carins and Rundle-Thiele, 2014; Kubacki et al., 2015) suggests there is a need for more studies to comprehensively test the effectiveness of such interventions. We limited our review to articles whose authors reported controlled weight loss results in relation to interventions at least partially supported by digital devices. This led our systematic review to focus on research in the medical field. This focus presents two limitations that should be noted. Firstly, a publication bias has been particularly highlighted in the medical field (Guyatt et al., 2011) and its possible impacts (Schmucker et al., 2017). While it seems unlikely that properly conducted studies could have led to negative results (weight gain), it is likely that a publication bias may have favoured the publication of positive results (versus nonconclusive results). Changing this state of affairs is beyond the reach of any review, but it is important that the limitation be mentioned and the calls for publication standards to mitigate this bias to be reiterated (Kittelman et al., 2018). Secondly, the medical articles in this review only provide partial information on the theoretical frameworks used for the development of the digital interventions and therefore do not enable theory-based recommendations. This may be a limitation of the reporting within the studies articles included in this review, or it may be an indication of a low level of theory use.

\section{Research avenues}

There is a general agreement in social science on the importance of integrating a theoretical framework to develop and evaluate programmes addressing health behavioural changes. Given the importance of theory in behaviour change (Rundle-Thiele et al., 2019), we suggest future studies should embed strong theory within the intervention and compare digital versions against both traditional delivery modes and no treatment controls to rigorously test efficacy. This review also highlights the importance of adopting a rigorous methodology when reporting social marketing interventions. Many interventions were not included in this review because they did not provide complete or quantitative data on the results. Developing and using strong evaluation methodologies will assist social marketers to demonstrate the efficacy of their discipline. 


\section{Implications for practice and public policy}

Some studies in this review found digital intervention to be effective (compared to a control), but versions supplemented with human elements to be even more effective. One of the recognised advantages of digital programmes is the potential to extend reach at low cost. Therefore, developing interventions that combine digital elements within traditional programmes may reduce the cost of individualised programmes but retain some advantages, such as the human touch, of traditional programmes. Given their low cost and the size of the overweight population, it appears that public policies should integrate these digital technologies more strongly in their efforts to combat obesity. Others have noted that digital technologies are increasingly used in social marketing to augment programmes rather than completely replace traditional forms (Kubacki et al., 2015), which suggests that combined modes are a promising avenue for future research. The use of digital devices also appears promising because it offers advantages for creating targeted and segmented intervention programmes. Research has shown that programmes that include different strategies designed for different segments can offer solutions that are more closely aligned to needs and wants of each segment and may improve outcomes (Dietrich et al., 2015). Algorithms make it possible to programme personalised elements based on the existing data of the participants, which suggests that digital applications may be important for segmented programmes.

\section{Implications for interactions with consumers}

Social marketing has long recognised the importance of a strong consumer orientation and increasingly the need to co-create programmes with users (Dietrich et al., 2016). It was rare for studies in this review to include consumers in the creation of programmes. With the exception of Patrick et al. (2009), researchers did not report that consumers participated in the creation of the programme. Yet, a rich literature indicates that customer involvement reinforces the perceived quality of service (Bitner et al., 1997). As noted by Prahalad and Ramaswamy, "the interaction between the (organization) and the consumer is becoming the locus of value creation and value extraction" (Prahalad and Ramaswamy, 2004:5). The cocreation of digitally based or digitally supported programmes thus seems to be a promising way to improve the proposed programmes. Along the same lines, the use of social media, as shown by Shawky et al. (2019) is likely to be a promising way to build engagement with the desired behavioural change. 


\section{Conclusion}

Social marketing continues to evolve and pursue innovation to enhance the delivery of programmes (French and Russell-Bennett, 2015; Kubacki and Rundle-Thiele, 2017; RundleThiele et al., 2019; Wymer, 2011). Underpinned by principles that include consumer orientation and value delivery (Andreasen, 2002; French and Russell-Bennett, 2015), and social marketing requires an understanding of the contemporary life of consumers and the production of solutions that people will value. Given the digital nature of today's society both are likely to involve digital technology. Incorporating digital technologies into social marketing programmes offer effective ways to increase reach and engagement, delivering similar outcomes more cost-effectively (Cugelman et al., 2011). This review indicates the potential for digital interventions to encourage weight loss and weight management and emphasises the need for further research to rigorously develop and test digital interventions in this behavioural context. Future social marketing programmes can use digital technologies to not only increase programme reach and efficiency but also to enhance the value users ascribe to the programme by co-creating digital programmes with users and by taking advantage of the nature of digital platforms to deliver elements that users want and need at convenient and appropriate times.

\section{References}

Abraham, C. and Michie, S. (2008), “A taxonomy of behaviour change techniques used in interventions", Health Psychology, Vol. 27 No. 3, p. 379.

Ajzen, I. (1991), "The theory of planned behaviour", Organizational Behavior and Human Decision Processes, Vol. 50 No. 2, pp. 179-211.

Albarracín, D., Gillette, J.C., Earl, A.N., Glasman, L.R., Durantini, M.R. and Ho, M.H. (2005), "A test of major assumptions about behaviour change: a comprehensive look at the effects of passive and active HIV-prevention interventions since the beginning of the epidemic", Psychological Bulletin, Vol. 131 No. 6, p. 131.

Andreasen, A.R. (2002), "Marketing social marketing in the social change marketplace", Journal of Public Policy and Marketing, Vol. 21 No. 1, pp. 3-13.

Angus, K., Cairn, G., Purves, R., Brice, S., McDonald, L. and Gordon, R. (2013), Systematic Literature Review to Examine the Evidence for the Effectiveness of Interventions That Use Theories and Models of Behaviour Change: Toward the Prevention and Control of Communicable Diseases, Stokholm, ECDC.

Bandura, A. (1976), Social Learning Theory, Englewood Cliffs, NJ: Prentice Hall. 
Bandura, A. (1986), "The explanatory and predictive scope of self-efficacy theory", Journal of Social and Clinical Psychology, Vol. 4 No. 3, pp. 359-373.

Bandura, A. (1998), "Personal and collective efficacy in human adaptation and change", Advances in Psychological Science, Vol. 1, pp. 51-71.

Beleigoli, A.M., Andrade, A.Q., Cançado, A.G., et al. (2019), "Web-based digital health interventions for weight loss and lifestyle habit changes in overweight and obese adults: systematic review and Meta-analysis", Journal of Medical Internet Research, Vol. 21 No. 1, p. e298.

Bitner, J., Faranda, W.T., Hubbert, A.R. and Zeithaml, V.A. (1997), “Customer contributions and roles in service delivery”, International Journal of Service Industry Management, Vol. 8 No. 3, pp. 193-205.

Brindal, E., Hendrie, G.A., Freyne, J. and Noakes, M. (2018), "Incorporating a static versus supportive mobile phone app into a partial meal replacement program with face-to-Face support: Randomized controlled trial”, JMIR mHealth and Uhealth, Vol. 6 No. 4.

Brug, J., Glanz, K., Van Assema, P., Kok, G. and Van Breukelen, G.J. (1998), “The impact of computertailored feedback and iterative feedback on fat, fruit, and vegetable intake", Health Education and Behavior, Vol. 25 No. 4, pp. 517-531.

Burke, L.E., Conroy, M.B., Sereika, S.M., Elci, O.U., Styn, M.A., Acharya, S.D., ... Glanz, K. (2011), "The effect of electronic self-monitoring on weight loss and dietary intake: a randomized behavioural weight loss trial", Obesity, Vol. 19 No. 2, pp. 338-344.

Campbell, M.K., DeVellis, B.M., Strecher, V.J., Ammerman, A.S., DeVellis, R.F. and Sandler, R.S. (1994), "Improving dietary behavior: the effectiveness of tailored messages in primary care settings", American Journal of Public Health, Vol. 84 No. 5, pp. 783-787.

Carins, J.E. and Rundle-Thiele, S.R. (2014), "Eating for the better: a social marketing review (2000- 2012)”, Public Health Nutrition, Vol. 17 No. 7, pp. 1628-1639.

Cugelman, B., Thelwall, M. and Dawes, P. (2011), “Online interventions for social marketing health behavior change campaigns: a Meta-analysis of psychological architectures and adherence factors", Journal of Medical Internet Research, Vol. 13 No. 1, p. e17.

Dibb, S. (2017), "Changing times for social marketing segmentation", In Segmentation in Social Marketing, (pp. 41-59). Springer, Singapore.

DiClemente, C.C., Marinilli, A.S., Singh, M. and Bellino, L.E. (2001), “The role of feedback in the process of health behavior change", American Journal of Health Behavior, Vol. 25 No. 3, pp. 217-227. 
Dietrich, T., Rundle-Thiele, S., Schuster, L. and Connor, J. (2016), "Co-designing social marketing programs", Journal of Social Marketing, Vol. 6 No. 1,

Domecq, J.P., Prutsky, G., Leppin, A., Sonbol, M.B., Altayar, O., Undavalli, C., Wang, Z., Elraiyah, T., Brito, J.P., Mauck, K.F. and Lababidi, M.H. (2015), "Drugs commonly associated with weight change: a systematic review and Meta-analysis", The Journal of Clinical Endocrinology and Metabolism, Vol. 100 No. 2, pp. 363-370.

ESMA (2017), "Global consensus on social marketing principles, concepts and techniques", from $\quad$ https://europeansocialmarketing.org/2017/08/19/global-consensus-on-socialmarketingprinciples-concepts-and-techniques/

Foy, R., Eccles, M.P., Jamtvedt, G., Young, J., Grimshaw, J.M. and Baker, R. (2005), "What do we know about how to do audit and feedback? Pitfalls in applying evidence from a systematic review", BMC Health Services Research, Vol. 5 No. 1, p. 50.

French, J. and Russell-Bennett, R. (2015), “A hierarchical model of social marketing”, Journal of Social Marketing, Vol. 5 No. 2, pp. 139-159.

Garnett, C., Crane, D., Brown, J., Kaner, E., Beyer, F., Muirhead, C., ... Michie, S. (2018), "Reported theory use by digital interventions for hazardous and harmful alcohol consumption, and association with effectiveness: Meta-regression”, Journal of Medical Internet Research, Vol. 20 No. 2, p. e69.

GBD 2015 Obesity Collaborators (2017), "Health effects of overweight and obesity in 195 countries over 25 years", New England Journal of Medicine, Vol. 377 No. 1, pp. 13-27.

Gill, T., King, L. and Caterson, I. (2005), "Obesity prevention: necessary and possible. A structured approach for effective planning”, Proceedings of the Nutrition Society, Vol. 64 No. 2, pp. 255-261.

Gold, B.C., Burke, S., Pintauro, S., Buzzell, P. and Harvey-Berino, J. (2007), "Weight loss on the web: a pilot study comparing a structured behavioural intervention to a commercial program", Obesity, Vol. 15 No. 1, pp. 155-155.

Gordon, R., McDermott, L., Stead, M. and Angus, K. (2006), "The effectiveness of social marketing interventions for health improvement: what's the evidence? ", Public Health, Vol. 120 No. 12, pp. 1133.1139.

Gurevitch, J., Koricheva, J., Nakagawa, S. and Stewart, G. (2018), "Meta-analysis and the science of research synthesis", Nature, Vol. 555 No. 7695, p. 175.

Guyatt, G.H., Oxman, A.D., Montori, V., Vist, G., Kunz, R., Brozek, J., Alonso-Coello, P., Djulbegovic, B., Atkins, D., Falck-Ytter, Y. and Williams, J.W. Jr (2011),“GRADE 
guidelines: 5. Rating the quality of evidence-publication bias", Journal of Clinical Epidemiology, Vol. 64 No. 12, pp. 1277-1282.

Haapala, I., Barengo, N.C., Biggs, S., Surakka, L. and Manninen, P. (2009), "Weight loss by mobile phone: a 1-year effectiveness study", Public Health Nutrition, Vol. 12 No. 12, pp. 2382-2391.

Harvey-Berino, J., West, D., Krukowski, R., Prewitt, E., VanBiervliet, A., Ashikaga, T. and Skelly, J. (2010), "Internet delivered behavioural obesity treatment", Preventive Medicine, Vol. 51 No. 2, pp. 123-128.

Hawkes, C., Smith, T.G., Jewell, J., Wardle, J., Hammond, R.A., Friel, S., ... Kain, J. (2015), "Smart food policies for obesity prevention", The Lancet, Vol. 385 No. 9985, pp. 24102421.

Hekler, E.B., Michie, S., Pavel, M., Rivera, D.E., Collins, L.M., Jimison, H.B., ... Spruijt-Metz, D. (2016), "Advancing models and theories for digital behaviour change interventions", American Journal of Preventive Medicine, Vol. 51 No. 5, pp. 825-832.

Hempel, S., Miles, J.N., Booth, M.J., Wang, Z., Morton, S.C. and Shekelle, P.G. (2013), "Risk of bias: a simulation study of power to detect study-level moderator effects in Metaanalysis", Systematic Reviews, Vol. 2 No. 1, p. 107.

Higgins, E.T. (1998), "Promotion and prevention: regulatory focus as a motivational principle", Advances in Experimental Social Psychology, Vol. 30, pp. 1-46. Academic Press.

Hurkmans, E., Matthys, C., Bogaerts, A., Scheys, L., Devloo, K. and Seghers, J. (2018), "Faceto-face versus mobile versus blended weight loss program: randomized clinical trial", JMIR mHealth and Uhealth, Vol. 6 No. 1.

Johnson, F. and Wardle, J. (2011), “The association between weight loss and engagement with a webbased food and exercise diary in a commercial weight loss programme: a retrospective analysis", International Journal of Behavioral Nutrition and Physical Activity, Vol. 8 No. 1, p. 83 .

Kittelman, A., Gion, C., Horner, R.H., Levin, J.R. and Kratochwill, T.R. (2018), "Establishing journalistic standards for the publication of negative results", Remedial and Special Education, Vol. 39 No. 3, pp. 171-176.

Krukowski, R.A., Tilford, J.M., Harvey-Berino, J. and West, D.S. (2011), “Comparing behavioral weight loss modalities: incremental cost-effectiveness of an internet-based versus an in-person condition”, Obesity, Vol. 19 No. 8, pp. 1629-1635. 
Kubacki, K. and Rundle-Thiele, S. (2017), Expanding the Formative Research Toolkit Formative Research in Social Marketing, (pp. 1-9): Springer.

Kubacki, K., Rundle-Thiele, S., Schuster, L., Wessels, C. and Gruneklee, N. (2015), “Digital innovation in social marketing: a systematic literature of interventions using digital channels for engagement", Innovations in Social Marketing and Public Health Communication: Improving the Quality of Life for Individuals and Communities, pp. 49-66.

Leahey, T.M., LaRose, J.G., Fava, J.L. and Wing, R.R. (2011), "Social influences are associated with BMI and weight loss intentions in young adults", Obesity, Vol. 19 No. 6, pp. 1157-1162.

Lee, W., Chae, Y.M., Kim, S., Ho, S.H. and Choi, I. (2010), "Evaluation of a mobile phonebased diet game for weight control", Journal of Telemedicine and Telecare, Vol. 16 No. 5, pp. $270-275$.

Liberati, A., Altman, D.G., Tetzlaff, J., Mulrow, C., Gøtzsche, P.C., Ioannidis, J.P., ... Moher, D. (2009), "The PRISMA statement for reporting systematic reviews and Meta-analyses of studies that evaluate health care interventions: explanation and elaboration", PLoS Medicine, Vol. 6 No. 7, p. e1000100.

Lin, P.H., Grambow, S., Intille, S., Gallis, J.A., Lazenka, T., Bosworth, H., ... Corsino, L. (2018), "The association between engagement and weight loss through personal coaching and cell phone interventions in young adults: Randomized controlled trial",JMIR mHealth and Uhealth, Vol. 6 No. 10.

McKenzie-Mohr, D. (2000), "New ways to promote pro-environmental behaviour: promoting sustainable behaviour: an introduction to community-based social marketing”, Journal of Social Issues, Vol. 56 No. 3, pp. 543-554.

Mehmet, M., Roberts, R. and Nayeem, T. (2020), "Using digital and social media for health promotion: a social marketing approach for addressing co-morbid physical and mental health”, Australian Journal of Rural Health, Vol. 28 No. 2, pp. 149-158.

Michie, S. and Prestwich, A. (2010), "Are interventions theory-based? Development of a theory coding scheme", Health Psychology, Vol. 29 No. 1, p. 1.

Michie, S., Abraham, C., Eccles, M.P., Francis, J.J., Hardeman, W. and Johnston, M. (2011a), "Strengthening evaluation and implementation by specifying components of behaviour change interventions: a study protocol”, Implementation Science, Vol. 6 No. 1, p. 10.

Michie, S., Ashford, S., Sniehotta, F.F., Dombrowski, S.U., Bishop, A. and French, D.P. (2011b), "A refined taxonomy of behaviour change techniques to help people change their 
physical activity and healthy eating behaviours: the CALO-RE taxonomy", Psychology and Health, Vol. 26 No. 11, pp. 1479-1498.

Michie, S., Richardson, M., Johnston, M., Abraham, C., Francis, J., Hardeman, W., ... Wood, C.E. (2013), "The behaviour change technique taxonomy (v1) of 93 hierarchically clustered techniques: building an international consensus for the reporting of behaviour change interventions", Annals of Behavioral Medicine, Vol. 46 No. 1, pp. 81-95.

Mohr, D., Cuijpers, P. and Lehman, K. (2011), "Supportive accountability: a model for providing human support to enhance adherence to eHealth interventions", Journal of Medical Internet Research, Vol. 13 No. 1, p. e30.

Mory, E.H. (2004), "Feedback research revisited", Handbook of Research on Educational Communications and Technology, Vol. 2, pp. 745-783.

Napolitano, M.A., Hayes, S., Bennett, G.G., Ives, A.K. and Foster, G.D. (2013), "Using Facebook and text messaging to deliver a weight loss program to college students", Obesity, Vol. 21 No. 1, pp. 25-31.

Oosterveen, E., Tzelepis, F., Ashton, L. and Hutchesson, M.J. (2017), “A systematic review of eHealth behavioural interventions targeting smoking, nutrition, alcohol, physical activity and/or obesity for young adults”, Preventive Medicine, Vol. 99, pp. 197-206.

Patrick, K., Raab, F., Adams, M.A., Dillon, L., Zabinski, M., Rock, C.L., ... Norman, G.J. (2009), “A text message-based intervention for weight loss: randomized controlled trial”, Journal of Medical Internet Research, Vol. 11 No. 1, p. 11.

Prahalad, C.K. and Ramaswamy, V. (2004), "Co-creation experiences: the next practice in value creation”, Journal of Interactive Marketing, Vol. 18 No. 3, pp. 5-14.

Puhl, R.M., Latner, J.D., O’Brien, K., Luedicke, J., Daníelsdottir, S. and Forhan, M. (2015), "A multinational examination of weight bias: predictors of anti-fat attitudes across four countries", International Journal of Obesity, Vol. 39 No. 7, p. 1166.

Rivera, J., McPherson, A., Hamilton, J., Birken, C., Coons, M., Iyer, S., ... Stinson, J. (2016), "Mobile apps for weight management: a scoping review", JMIR mHealth and Uhealth, Vol. 4 No. 3 , p. e87.

Rundle-Thiele, S. (2015), "Rétrospective et perspective d'avenir: un plan d'action pour la recherche en marketing social", Recherche et Applications en Marketing, Vol. 30 No. 3, pp. 133-139.

Rundle-Thiele, S., David, P., Willmott, T., Pang, B., Eagle, L. and Hay, R. (2019), "Social marketing theory development goals: an agenda to drive change", Journal of Marketing Management, Vol. 35 Nos 1/2, pp. 160-181. 
Schmucker, C.M., Blümle, A., Schell, L.K., Schwarzer, G., Oeller, P., Cabrera, L., von Elm, E., Briel, M. and Meerpohl, J.J. and OPEN consortium (2017), "Systematic review finds that study data not published in full text articles have unclear impact on Meta-analyses results in medical research", PloS One, Vol. 12 No. 4, p. e0176210.

Serrano, K.J., Yu, M., Coa, K.I., Collins, L.M. and Atienza, A.A. (2016), "Mining health app data to find more and less successful weight loss subgroups", Journal of Medical Internet Research, Vol. 18 No. 6, p. 18.

Shapiro, J.R., Koro, T., Doran, N., Thompson, S., Sallis, J.F., Calfas, K. and Patrick, K. (2012), "Text4Diet: a randomized controlled study using text messaging for weight loss behaviors", Preventive Medicine, Vol. 55 No. 5, pp. 412-417.

Shaw, R.J., Bosworth, H.B., Silva, S.S., Lipkus, I.M., Davis, L.L., Ronald, S.S. and Johnson, C.M. (2013), "Mobile health messages help sustain recent weight loss", The American Journal of Medicine, Vol. 126 No. 11, pp. 1002-1009.

Shawky, S., Kubacki, K., Dietrich, T. and Weaven, S. (2019), "Using social media to create engagement: a social marketing review", Journal of Social Marketing, Vol. 9 No. 2, pp. 204224.

Svetkey, L.P., Batch, B.C., Lin, P.H., Intille, S.S., Corsino, L., Tyson, C.C., Bosworth, H.B., Grambow, S.C., Voils, C., Loria, C. and Gallis, J.A. (2006), “Cell phone intervention for you (CITY): a randomized, controlled trial of behavioral weight loss intervention for young adults using mobile technology”, Obesity, Vol. 23 No. 11, pp. 2133-2141.

Tate, D.F., Jackvony, E.H. and Wing, R.R. (2006), “A randomized trial comparing human email counselling, computer-automated tailored counselling, and no counselling in an internet weight loss program", Archives of Internal Medicine, Vol. 166 No. 15, pp. 16201625 .

Tettey, N.-S. (2011), “An online evaluation of a new web-based source of information on eating healthy and being active designed for African American women: exploring relationships among personal-level variables and website ratings". PhD Thesis, Columbia University.

Truong, V.D. (2014), “Social marketing: a systematic review of research 1998-2012”, Social Marketing Quarterly, Vol. 20 No. 1, pp. 15-34.

Turner-McGrievy, G. and Tate, D. (2011), “Tweets, apps, and pods: results of the 6-month mobile pounds off digitally (mobile POD) randomized weight-loss intervention among adults", Journal of Medical Internet Research, Vol. 13 No. 4, p. 13. 
Webb, T., Joseph, J., Yardley, L. and Michie, S. (2010), "Using the internet to promote health behaviour change: a systematic review and Meta-analysis of the impact of theoretical basis, use of behaviour change techniques, and mode of delivery on efficacy", Journal of Medical Internet Research, Vol. 12 No. 1, p. e4.

West, J.H., Hall, P.C., Arredondo, V., Berrett, B., Guerra, B. and Farrell, J. (2013), "Health behaviour theories in diet apps", Journal of Consumer Health on the Internet, Vol. 17 No. 1, pp. 10-24.

WHO (World Health Organization) (2018), Obesity and Overweight. Fact Sheet (Updated February 2018), World Health Organization, Geneva, www.who.int/news-room/factsheets/detail/obesityand-overweight (last accessed July 25th, 2019).

Willmott, T., Pang, B., Rundle-Thiele, S. and Badejo, A. (2019a), "Reported theory use in electronic health weight management interventions targeting young adults: a systematic review", Health Psychology Review, Vol. 13 No. 3, pp. 295-317.

Willmott, T.J., Pang, B., Rundle-Thiele, S. and Badejo, A. (2019b), "Weight management in young adults: systematic review of electronic health intervention components and outcomes", Journal of Medical Internet Research, Vol. 21 No. 2, p. e10265

Wing, R.R. and Jeffery, R.W. (1999), "Benefits of recruiting participants with friends and increasing social support for weight loss and maintenance", Journal of Consulting and Clinical Psychology, Vol. 67 No. 1, p. 132.

Womble, L.G., Wadden, T.A., McGuckin, B.G., Sargent, S.L., Rothman, R.A. and Krauthamer-Ewing, E. S. (2004), “A randomized controlled trial of a commercial internet weight loss program", Obesity Research, Vol. 12 No. 6, pp. 1011-1018.

Wymer, W. (2011), "Developing more effective social marketing strategies”, Journal of Social Marketing, Vol. 1 No. 1, pp. 17-31.

Xia, Y., Deshpande, S. and Bonates, T. (2016), "Effectiveness of social marketing interventions to promote physical activity among adults: a systematic review", Journal of Physical Activity and Health, Vol. 13 No. 11, pp. 1263-1274. 


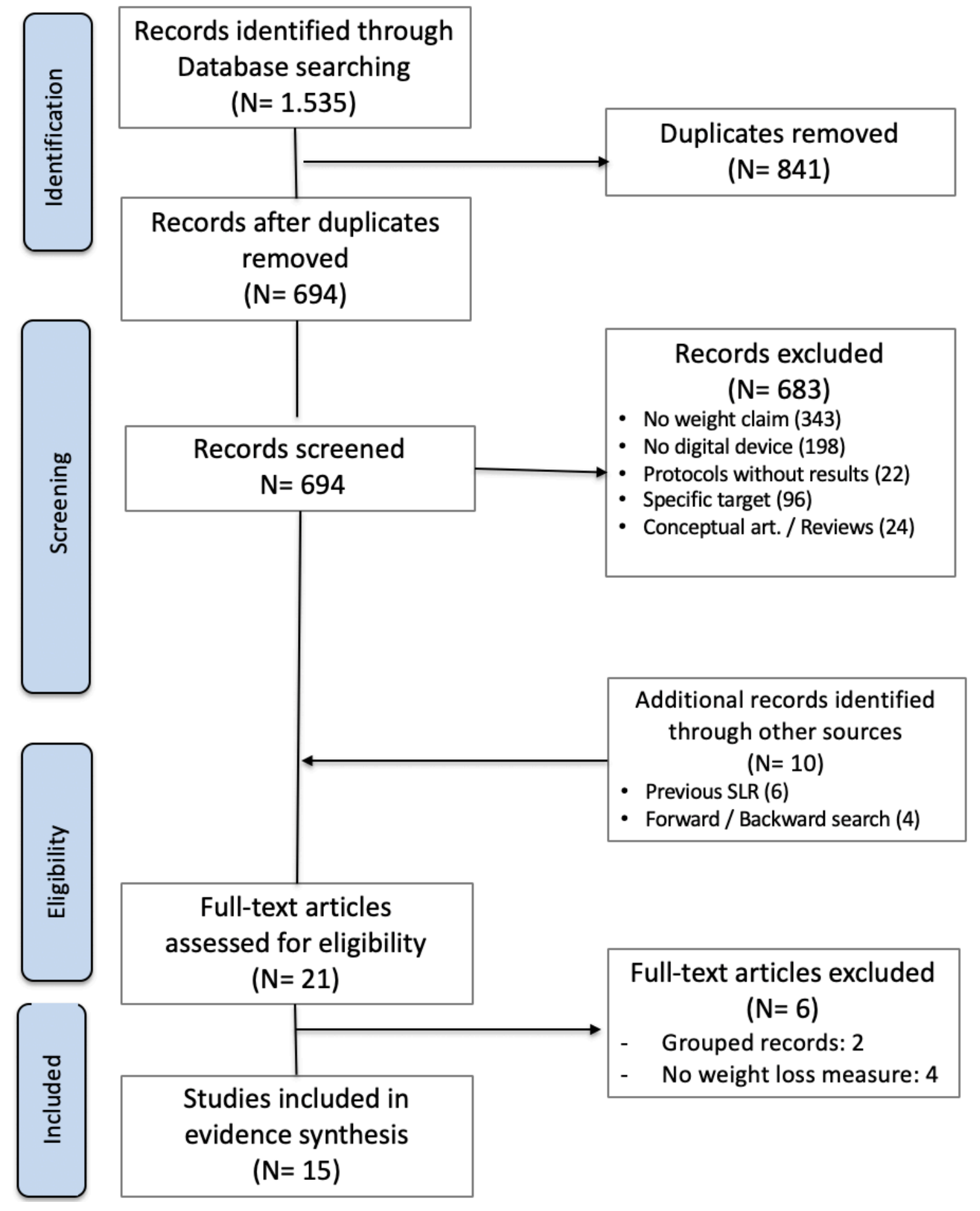

Figure 1: PRISMA flowchart of study selection process 
1 Table 1. Description of the studies included in the SLR

\begin{tabular}{|c|c|c|c|c|c|}
\hline $\begin{array}{c}\text { Studies } \\
\text { 2018-2004 } \\
\end{array}$ & $\begin{array}{l}\text { Sample \& } \\
\text { duration }\end{array}$ & $\begin{array}{l}\text { Study } \\
\text { Objective(s) }\end{array}$ & $\begin{array}{c}\text { Behavioural } \\
\text { Objective }\end{array}$ & Intervention Treatments & Findings \\
\hline $\begin{array}{l}\text { Brindal et al., } \\
2018 \\
\text { JMIR }\end{array}$ & $\begin{array}{l}146 \text { overweight } \\
\text { adults } \\
\text { AUSTRALIA } \\
24 \text { weeks }\end{array}$ & $\begin{array}{l}\text { Evaluate efficacy } \\
\text { of two mobile } \\
\text { Apps } \\
\text { RCT }^{6} \text { ( } 2 \text { groups) } \\
\text { - Supportive App } \\
\text { - Static App }\end{array}$ & $\begin{array}{l}\text { WL through } \\
\text { partial meal } \\
\text { replacement }\end{array}$ & $\begin{array}{l}\text { Supportive: Tools to support behaviour } \\
\text { change and monitor progress and } \\
\text { compliance with behavioural objectives } \\
\text { Static: Information only }\end{array}$ & $\begin{array}{l}\text { - WL for both Supportive (6.7\%) and Static (5.4\%) groups at } 6 \\
\text { months. } \\
\text { - No sig. difference in mean WL for Supportive App compared to } \\
\text { Static App at } 6 \text { months. } \\
\text { - No sig. difference between groups in number of people achieving } \\
\text { clinically meaningful (>5\%) WL (exact proportions not reported) }\end{array}$ \\
\hline $\begin{array}{l}\text { Hurkmans et al., } \\
2018 \\
\text { JMIR }\end{array}$ & $\begin{array}{l}63 \text { overweight } \\
\text { adults } 18-65 \text { yrs } \\
\text { BELGIUM } \\
12 \text { weeks }\end{array}$ & $\begin{array}{l}\text { Evaluate efficacy } \\
\text { of mobile App } \\
\text { compared to } \\
\text { conventional (in- } \\
\text { person delivery) } \\
\text { RCT (4 groups) } \\
\text { - App } \\
\text { - Conventional } \\
\text { - Combined } \\
\text { - Control }\end{array}$ & $\begin{array}{c}\text { WL through diet } \\
\text { and PA }\end{array}$ & $\begin{array}{l}\text { App: Digital diet \& PA advice and tools to } \\
\text { support behaviour change and option for } \\
\text { social support } \\
\text { Conventional: Personalised plan and } \\
\text { coaching sessions } \\
\text { Combined: Digital diet \& PA advice and tools } \\
\text { to support behaviour change and option for } \\
\text { social support PLUS Personalised plan and } \\
\text { half number conventional coaching sessions } \\
\text { Control: waitlist (nothing provided) }\end{array}$ & $\begin{array}{l}\text { - Absolute } \mathrm{WL} \text { (or \% WL) for each group not reported } \\
\text { - Sig. more participants in all } 3 \text { intervention groups had clinically } \\
\text { meaningful ( }>5 \%) \mathrm{WL} \text { compared to Control group (numbers not } \\
\text { reported) } \\
\text { - Combined group had higher number of people with }>5 \% \mathrm{WL} \text {, and } \\
\text { decreased BMI, compared to App group (but not Conventional } \\
\text { group). No sig. diff. between the Conventional group and App } \\
\text { group for people }>5 \% \mathrm{WL} \text {, and decreased BMI. (Exact proportions } \\
\text { within each group not reported). }\end{array}$ \\
\hline $\begin{array}{l}\text { Svetkey et al., } \\
2015 \\
\text { Obesity } \\
\text { Lin, Grambov et } \\
\text { al., } 2018 \\
\text { JMIR }\end{array}$ & $\begin{array}{l}207 \text { overweight } \\
\text { adults } \\
\text { USA } \\
104 \text { weeks }\end{array}$ & $\begin{array}{l}\text { Evaluate efficacy } \\
\text { of mobile App } \\
\text { compared to } \\
\text { conventional (in- } \\
\text { person delivery) } \\
\text { RCT ( } 3 \text { groups) } \\
\text { - App } \\
\text { - Coaching } \\
\text { - Control }\end{array}$ & $\begin{array}{l}\text { WL through } \\
\text { moderate calorie } \\
\text { restriction, } \\
\text { healthy dietary } \\
\text { pattern, } \\
\text { moderate PA, } \\
\text { limited alcohol }\end{array}$ & $\begin{array}{l}\text { App: Tools to set goals, manage behaviours } \\
\text { and monitor progress. Included prompts and } \\
\text { social support (buddy) } \\
\text { Coaching: Six weekly sessions with coach and } \\
\text { monthly calls (social support). App used to } \\
\text { self-monitor progress, which is fed through } \\
\text { to coach } \\
\text { Control: Diet and exercise handouts }\end{array}$ & $\begin{array}{l}\text { - WL for App group: 0.87kg }(6 \mathrm{~m}), 1.48 \mathrm{~kg}(12 \mathrm{~m}) \& 0.99 \mathrm{~kg}(24 \mathrm{~m}) ; \\
\text { Coaching group: } 3.07 \mathrm{~kg}(6 \mathrm{~m}) 3.58 \mathrm{~kg}(12 \mathrm{~m}) \& 2.45 \mathrm{~kg}(24 \mathrm{~m}) ; \\
\text { Control: } 1.14 \mathrm{~kg}(6 \mathrm{~m}), 2.25 \mathrm{~kg}(12 \mathrm{~m}) \& 1.44 \mathrm{~kg}(24 \mathrm{~m}) \text {. } \\
\text { - No sig. differences in mean WL between groups at } 24 \text { months. } \\
\text { - App group did not differ from Control at any measurement point } \\
\text { (6, } 12 \text { \& } 24 \text { months); Coaching group lost sig. more weight than } \\
\text { Control at } 6 \text { months, but not at } 12 \text { and } 24 \text { months. } \\
\text { - Percentage of participants with clinically meaningful }(>5 \%) \mathrm{WL} \text { at } \\
24 \mathrm{~m} \text { did not differ between groups (App=25.5\%, Coaching=27.5\%, } \\
\text { and Control=22.0\%). } \\
\text { - Engagement is correlated to WL for both interventions at } 6 \mathrm{~m} \text {; } \\
\text { engagement correlated to WL in Coaching group at } 12 \mathrm{~m} \text { (but not } \\
\text { in App group). }\end{array}$ \\
\hline
\end{tabular}

${ }^{6} \mathrm{RCT}$ : randomized controlled trial 


\begin{tabular}{|c|c|c|c|c|c|}
\hline $\begin{array}{c}\text { Studies } \\
2018-2004\end{array}$ & $\begin{array}{l}\text { Sample \& } \\
\text { duration }\end{array}$ & $\begin{array}{l}\text { Study } \\
\text { Objective(s) }\end{array}$ & $\begin{array}{c}\text { Behavioural } \\
\text { Objective }\end{array}$ & Intervention Treatments & Findings \\
\hline $\begin{array}{l}\text { Napolitano et al., } \\
2013 \\
\text { Obesity }\end{array}$ & $\begin{array}{l}52 \text { college } \\
\text { students } \\
\text { USA } \\
8 \text { weeks }\end{array}$ & $\begin{array}{l}\text { Evaluate efficacy } \\
\text { of Facebook- } \\
\text { based program } \\
\text { RCT (3 groups) } \\
\text { - Facebook } \\
\text { - Facebook Plus } \\
\text { - Control } \\
\end{array}$ & $\begin{array}{l}\text { WL through } \\
\text { calorie control, } \\
\text { moderate PA }\end{array}$ & $\begin{array}{l}\text { Facebook: Private Facebook group with } \\
\text { handouts and podcasts and invitation to } \\
\text { healthy activity and eating events. } \\
\text { Facebook Plus: Private Facebook group with } \\
\text { handouts and podcasts and invitation to } \\
\text { healthy activity and eating events Plus Daily } \\
\text { SMS and feedback and social support } \\
\text { Control: waitlist (nothing provided) } \\
\end{array}$ & $\begin{array}{l}\text { WL for Facebook group: 0.46kg (4w), } 0.63 \mathrm{~kg}(8 \mathrm{w}) \text {; Facebook Plus } \\
\text { group: } 1.7 \mathrm{~kg}(4 \mathrm{w}), 2.4 \mathrm{~kg}(8 \mathrm{w}) ; \text { and Control group: } 0.28 \mathrm{~kg}(4 \mathrm{w}) \text {, } \\
0.24 \mathrm{~kg}(8 \mathrm{w}) . \\
\text { - Facebook Plus group had sig. greater weight loss than Facebook } \\
\text { and Control groups at } 2 \text { months. No sig diff between Facebook } \\
\text { and Control groups at } 2 \text { months. } \\
\text { - (Proportion of participants achieving clinically meaningful WL } \\
\text { (>5\%) not reported). }\end{array}$ \\
\hline $\begin{array}{l}\text { Shaw et al., } 2013 \\
\text { Am J Med } \\
\text { Shaw et al., } 2013 \\
\text { JMIR }\end{array}$ & $\begin{array}{l}120 \text { overweight } \\
\text { adults } \\
\text { USA } \\
12 \text { weeks }\end{array}$ & $\begin{array}{l}\text { Evaluate efficacy } \\
\text { of different types } \\
\text { of SMS messages } \\
\text { RCT (3 groups) } \\
\text { - Promotion } \\
\text { - Prevention } \\
\text { - Control }\end{array}$ & $\begin{array}{l}\text { WL through } \\
\text { regular PA, low- } \\
\text { calorie healthy } \\
\text { diet, and } \\
\text { monitoring body } \\
\text { weight }\end{array}$ & $\begin{array}{l}\text { Promotion: Messages framed on promotion } \\
\text { success (rewarding oneself) } \\
\text { Prevention: Messages based on preventing } \\
\text { failure (avoid temptation) } \\
\text { Control: General health messages }\end{array}$ & $\begin{array}{l}\text { - WL for Promotion group: } 14.6 \text { lbs }(3 \mathrm{~m}) \text {; Prevention group: } 15.3 \\
\text { Ibs }(3 \mathrm{~m}) \text {; Control:9.7 lbs ( } 3 \mathrm{~m}) \\
\text { - Sustained WL occurred in all groups, with no sig. diff between } \\
\text { groups at } 1 \text { month or } 3 \text { months. } \\
\text { - A priori pairwise comparisons found greater sustained WL in the } \\
\text { prevention group than control at } 3 \text { months, but no difference } \\
\text { between other pairs (prevention vs promotion; promotion vs } \\
\text { control). } \\
\text { (Proportion of participants achieving clinically meaningful WL } \\
(>5 \%) \text { not reported). }\end{array}$ \\
\hline $\begin{array}{l}\text { Shapiro et al., } \\
2012 \\
\text { Prev Med }\end{array}$ & $\begin{array}{l}170 \text { overweight } \\
\text { adults } \\
\text { USA } \\
52 \text { weeks }\end{array}$ & $\begin{array}{l}\text { Evaluate the } \\
\text { efficacy of SMS } \\
\text { messages } \\
\text { RCT ( } 2 \text { groups) } \\
\text { - SMS } \\
\text { - Control }\end{array}$ & $\begin{array}{c}\text { WL through } \\
\text { self-monitoring of } \\
\text { diet and exercise }\end{array}$ & $\begin{array}{l}\text { SMS: Daily SMS/MMS messages to provide } \\
\text { information, tips, reinforcement } \\
\text { Control: only monthly emails }\end{array}$ & $\begin{array}{l}\text { - WL for SMS group: } 3.72 \mathrm{lb}(6 \mathrm{~m}) 3.64 \mathrm{lb}(12 \mathrm{~m}) \text {; Control: } 1.53 \mathrm{lb} \\
(6 \mathrm{~m}) 2.27 \mathrm{lb}(12 \mathrm{~m}) \\
\text { - No sig. difference in mean WL between SMS and control at } 12 \\
\text { months. Participants with greater adherence (higher response } \\
\text { rate to self-monitoring requests) had greater WL at } 6 \text { and } 12 \\
\text { months. } \\
\text { - (Proportion of participants achieving clinically meaningful WL } \\
(>5 \%) \text { not reported). }\end{array}$ \\
\hline $\begin{array}{l}\text { Burke et al., } 2011 \\
\text { Am J Prev Med }\end{array}$ & $\begin{array}{l}210 \text { overweight } \\
\text { adults } \\
\text { USA } \\
24 \text { weeks }\end{array}$ & $\begin{array}{l}\begin{array}{l}\text { Evaluate the } \\
\text { efficacy of PDA } \\
\text { program }\end{array} \\
\text { RCT (3 groups) } \\
\text { - PDA } \\
\text { - PDA Plus } \\
\text { - Paper }\end{array}$ & \begin{tabular}{|c|} 
WL through \\
self-monitoring of \\
diet and exercise
\end{tabular} & $\begin{array}{l}\text { PDA: PDA equipped with self-monitoring } \\
\text { tools and weekly message } \\
\text { PDA Plus: PDA equipped with self-monitoring } \\
\text { tools and weekly message PLUS algorithm to } \\
\text { provide daily tailored feedback messages } \\
\text { Paper: paper diaries }\end{array}$ & $\begin{array}{l}\text { - WL for PDA group: 5.5\%; PDA Plus group: } 7.3 \% \text {; Paper: } 5.3 \% \\
\text { - No sig. diff between groups } \\
\text { - A higher proportion of PDA+ participants (63\%) achieved } \geq 5 \% \text { WL } \\
\text { compared to PDA (49\%) and Paper (46\%) groups. } \\
\text { - Higher adherence to self-monitoring was observed in both PDA } \\
\text { groups versus Paper group. }\end{array}$ \\
\hline
\end{tabular}




\begin{tabular}{|c|c|c|c|c|c|}
\hline $\begin{array}{c}\text { Studies } \\
2018-2004\end{array}$ & $\begin{array}{l}\begin{array}{l}\text { Sample \& } \\
\text { duration }\end{array} \\
\end{array}$ & $\begin{array}{l}\text { Study } \\
\text { Objective(s) }\end{array}$ & $\begin{array}{c}\text { Behavioural } \\
\text { Objective }\end{array}$ & Intervention Treatments & Findings \\
\hline $\begin{array}{l}\text { Turner-McGrievy } \\
\text { and Tate, } 2011 \\
\text { JMIR }\end{array}$ & $\begin{array}{l}96 \text { overweight } \\
\text { adults } \\
\text { USA } \\
24 \text { weeks }\end{array}$ & $\begin{array}{l}\text { Evaluate efficacy } \\
\text { of Podcast } \\
\text { programs } \\
\text { RCT ( } 2 \text { groups) } \\
\text { - Podcast } \\
\text { - Podcast + App }\end{array}$ & $\begin{array}{l}\text { WL through } \\
\text { calorie reduction } \\
\text { and increased PA }\end{array}$ & $\begin{array}{l}\text { Podcast: Access to website containing } \\
\text { podcasts } \\
\text { Podcast + App: Podcast features }+ \\
\text { monitoring application + interaction with } \\
\text { counselor and other participants on Twitter }\end{array}$ & $\begin{array}{l}\text { - WL for Podcast group: } 2.3 \mathrm{~kg}(3 \mathrm{~m}), 2.6 \mathrm{~kg}(6 \mathrm{~m}) \text {; Podcast + App } \\
\text { group: } 2.4 \mathrm{~kg}(3 \mathrm{~m}), 2.6 \mathrm{~kg}(6 \mathrm{~m}) \text {. } \\
\text { - No sig. diff. in mean WL between groups at } 6 \text { months. } \\
\text { - (Proportion of participants achieving clinically meaningful WL } \\
(>5 \%) \text { not reported) }\end{array}$ \\
\hline $\begin{array}{l}\text { Lee W, et al., } \\
2010 \\
J \text { Telemed } \\
\text { Telecare }\end{array}$ & $\begin{array}{l}36 \text { overweight } \\
\text { adults } \\
\text { KOREA } \\
6 \text { weeks }\end{array}$ & $\begin{array}{l}\text { Evaluate efficacy } \\
\text { of mobile App } \\
\text { Case-control trial } \\
\text { (2 groups) } \\
\text { - Gamification } \\
\text { - Control } \\
\end{array}$ & $\begin{array}{l}\text { WL through } \\
\text { calorie control } \\
\text { and exercise }\end{array}$ & $\begin{array}{l}\text { Gamification: Personalised information, } \\
\text { monitoring and gamification } \\
\text { Control: nothing provided }\end{array}$ & $\begin{array}{l}\text { - WL in Gamification group (1.9kg; } 3.2 \%) \text { compared to Control } \\
\text { (0.5kg; } 0.85 \%) \text { at } 6 \text { weeks. } \\
\text { - Sig greater mean WL in Gamification group. } \\
\text { - (Proportion of participants achieving clinically meaningful WL } \\
\text { (>5\%) not reported). }\end{array}$ \\
\hline $\begin{array}{l}\text { Harvey-Berino et } \\
\text { al., } 2010 \\
\text { Prev Med }\end{array}$ & $\begin{array}{l}480 \text { overweight } \\
\text { adults } \\
\text { USA } \\
26 \text { weeks }\end{array}$ & $\begin{array}{l}\begin{array}{l}\text { Evaluate efficacy } \\
\text { of an Internet- } \\
\text { based program }\end{array} \\
\text { RCT (3 groups) } \\
\text { - Internet } \\
\text { - In-person } \\
\text { - Hybrid }\end{array}$ & $\begin{array}{l}\text { WL through } \\
\text { calorie restriction } \\
\text { and exercise }\end{array}$ & $\begin{array}{l}\text { Internet: All components delivered through } \\
\text { the internet } \\
\text { In-person: Delivered in person } \\
\text { Hybrid: Weekly alternating in-person and } \\
\text { Internet }\end{array}$ & $\begin{array}{l}\text { - WL for In-person group (8kg); Internet group (6kg) hybrid group } \\
\text { (6kg) at } 6 \text { months } \\
\text { - Mean WL for In-person group sig. greater than Internet or hybrid } \\
\text { groups. } \\
\text { - No sig. diff. between groups for proportion achieving clinically } \\
\text { meaningful WL (>5\%) (In-person=65\%; hybrid=59\%; } \\
\text { Internet=53\%). } \\
\text { - Higher proportion achieving greater than clinically meaningful WL } \\
\text { (>7\%), for In-person group compared to Internet (but not Hybrid). } \\
\text { No sig. diff between Internet and Hybrid on this measure. } \\
\text { - No sig. diff. between groups in adherence. } \\
\text { - Sig. higher perceived social support for In-person group } \\
\text { compared to Internet (but not Hybrid). No sig. diff between } \\
\text { Internet and Hybrid on this measure. }\end{array}$ \\
\hline $\begin{array}{l}\text { Haapala et al., } \\
2009 \\
\text { Public Health } \\
\text { Nutr }\end{array}$ & $\begin{array}{l}125 \text { overweight } \\
\text { adults } \\
\text { FINLAND } \\
52 \text { weeks }\end{array}$ & $\begin{array}{l}\begin{array}{l}\text { Evaluate efficacy } \\
\text { of a mobile } \\
\text { phone based } \\
\text { program }\end{array} \\
\text { RCT ( } 2 \text { groups) } \\
\text { - Intervention } \\
\text { - Control }\end{array}$ & $\begin{array}{l}\text { WL through } \\
\text { self-directed diet } \\
\text { and exercise } \\
\text { modification }\end{array}$ & $\begin{array}{l}\text { Intervention: Support program for self- } \\
\text { directed dieters. Self-reporting of intake, PA } \\
\text { and weight produced automatic tailored } \\
\text { SMS } \\
\text { Control: waitlist (nothing provided) }\end{array}$ & $\begin{array}{l}\text { - WL in Intervention group (4.5kg); Control (1.1kg) at } 12 \text { months. } \\
\text { - Sig. greater mean WL in Intervention group compared to Control } \\
\text { - The percentage achieving clinically meaningful }(>5 \%) \text { WL was } 45 \% \\
\text { in the Intervention group and } 20 \% \text { in the control group. }\end{array}$ \\
\hline
\end{tabular}




\begin{tabular}{|c|c|c|c|c|c|}
\hline $\begin{array}{c}\text { Studies } \\
\text { 2018-2004 }\end{array}$ & $\begin{array}{l}\text { Sample \& } \\
\text { duration }\end{array}$ & $\begin{array}{l}\text { Study } \\
\text { Objective(s) }\end{array}$ & $\begin{array}{c}\text { Behavioural } \\
\text { Objective }\end{array}$ & Intervention Treatments & Findings \\
\hline $\begin{array}{l}\text { Patrick et al., } \\
2009 \\
\text { J Med Internet } \\
\text { Res }\end{array}$ & $\begin{array}{l}65 \text { overweight } \\
\text { adults } \\
\text { USA } \\
16 \text { weeks }\end{array}$ & $\begin{array}{l}\text { Evaluate the } \\
\text { efficacy of SMS } \\
\text { messages } \\
\text { RCT ( } 2 \text { groups) } \\
\text { - Intervention } \\
\text { - Comparison }\end{array}$ & $\begin{array}{l}\text { WL through } \\
\text { self-monitoring of } \\
\text { diet and exercise }\end{array}$ & $\begin{array}{l}\text { Intervention: Personalised SMS and MMS (2- } \\
5 \text { day), brief monthly phone call from health } \\
\text { counsellor } \\
\text { Comparison: Monthly print materials }\end{array}$ & $\begin{array}{l}\text { - WL in Intervention group ( } 2.9 \mathrm{~kg} ; 3.2 \%) \text {; Comparison }(0.9 \mathrm{~kg} ; 1 \%) \\
\text { at } 4 \text { months. } \\
\text { Sig. greater mean WL in Intervention group compared to } \\
\text { comparison } \\
\text { - (Proportion of participants achieving clinically meaningful WL } \\
\text { ( }>5 \%) \text { not reported). }\end{array}$ \\
\hline $\begin{array}{l}\text { Gold et al., } 2007 \\
\text { Obesity }\end{array}$ & $\begin{array}{l}125 \text { overweight } \\
\text { adults } \\
\text { USA } \\
48 \text { weeks }\end{array}$ & $\begin{array}{l}\text { Evaluate efficacy } \\
\text { of online } \\
\text { programs } \\
\text { RCT ( } 2 \text { groups) } \\
\text { - Vtrim } \\
\text { - eDiets.com }\end{array}$ & $\begin{array}{l}\text { WL through } \\
\text { modification of } \\
\text { diet and exercise }\end{array}$ & $\begin{array}{l}\text { Vtrim: Therapist-led structured online } \\
\text { program with weekly chat with therapist } \\
\text { eDiets.com: Self-help commercial online } \\
\text { program }\end{array}$ & $\begin{array}{l}\text { - WL in VTrim group ( } 7.3 \mathrm{~kg} \text { ); eDiets.com group ( } 3.6 \mathrm{~kg} \text { ) at } 6 \text { months } \\
\text { (results for completers) } \\
\text { - Sig. greater mean WL in VTrim group than eDiets.com group. } \\
\text { - VTrim group maintained a sig higher mean WL (5.5kg) compared } \\
\text { to eDiets.com group ( } 2.8 \mathrm{~kg} \text { ) at } 12 \text { months (results for } \\
\text { completers). } \\
\text { - Sig. more participants achieved clinically meaningful }(>5 \%) \mathrm{WL} \text { in } \\
\text { the VTrim group (65\%) compared to eDiets.com group (37.5\%) at } \\
12 \text { months. }\end{array}$ \\
\hline $\begin{array}{l}\text { Tate et al., } 2006 \\
\text { Arch Int Med }\end{array}$ & $\begin{array}{l}193 \text { overweight } \\
\text { adults } \\
\text { USA } \\
26 \text { weeks }\end{array}$ & $\begin{array}{l}\text { Evaluate efficacy } \\
\text { of computer- } \\
\text { tailored } \\
\text { counselling } \\
\text { RCT ( } 3 \text { groups) } \\
\text { - HC } \\
\text { - AC } \\
\text { - Control }\end{array}$ & $\begin{array}{l}\text { WL through } \\
\text { calorie restricted } \\
\text { diet, meal } \\
\text { replacement and } \\
\quad \text { exercise }\end{array}$ & $\begin{array}{l}\text { HC (Human counselling): access to an } \\
\text { electronic diary and message board + weekly } \\
\text { e-mail feedback from a counsellor } \\
\text { AC (Automated counselling): access to an } \\
\text { electronic diary and message board + } \\
\text { automated, tailored messages } \\
\text { Control: no feedback }\end{array}$ & $\begin{array}{l}\text { - WL for AC group: } 5.3 \mathrm{~kg}(3 \mathrm{~m}), 7.3 \mathrm{~kg}(6 \mathrm{~m}) ; \mathrm{HC} \text { group: } 6.1 \mathrm{~kg}(3 \mathrm{~m}) \text {, } \\
4.9 \mathrm{~kg}(6 \mathrm{~m}) ; \text { Control: } 2.8 \mathrm{~kg}(3 \mathrm{~m}), 2.6 \mathrm{~kg}(6 \mathrm{~m}) \text { (results for } \\
\text { completers). } \\
\text { - Sig. greater WL in AC and HC groups compared to Control. No sig. } \\
\text { diff. between AC and HC group at } 3 \text { months. } \\
\text { - Sig. greater WL by completers in HC compared to AC group and } \\
\text { Control at } 6 \text { months. } \\
\text { - Sig. more participants achieved clinically meaningful }(>5 \%) \mathrm{WL} \text { in } \\
\text { the HC group (52\%) compared to the Control group }(27 \%) \text { at } 6 \\
\text { months. The AC group }(34 \%) \text { did not differ from the other groups. }\end{array}$ \\
\hline $\begin{array}{l}\text { Womble et al., } \\
2004 \\
\text { Obesity }\end{array}$ & $\begin{array}{l}48 \text { overweight } \\
\text { women } \\
\text { USA } \\
52 \text { weeks }\end{array}$ & $\begin{array}{l}\text { Evaluate efficacy } \\
\text { of online program } \\
\text { RCT ( } 2 \text { groups) } \\
\text { - eDiets.com } \\
\text { - Paper }\end{array}$ & $\begin{array}{c}\text { WL through } \\
\text { modification of } \\
\text { diet and exercise }\end{array}$ & $\begin{array}{l}\text { eDiets.com: Self-help commercial online } \\
\text { program } \\
\text { Paper: Lesson book for modifying eating, } \\
\text { activity (16 lessons) }\end{array}$ & $\begin{array}{l}\text { - WL for eDiets.com group } 0.7 \mathrm{~kg}(0.9 \%) \text { at } 16 \mathrm{w} ; 0.8 \mathrm{~kg}(1.1 \%) \text { at } \\
52 \mathrm{w} \text {; paper group } 3.0 \mathrm{~kg}(3.6 \%) \text { at } 16 \mathrm{w} ; 3.3 \mathrm{~kg}(4.0 \%) \text { at } 52 \mathrm{w} \\
\text { Differences in mean WL between eDiets.com group and paper } \\
\text { group at } 16 \mathrm{w} \text { and } 52 \mathrm{w} \text { were found not to be significant when } \\
\text { conducted using completers only. } \\
\text { (Proportion of participants achieving clinically meaningful WL } \\
(>5 \%) \text { not reported). }\end{array}$ \\
\hline
\end{tabular}


4 Table 2. Behaviour change theories and techniques, technical device and efficacy on weight loss

\begin{tabular}{|c|c|c|c|c|c|c|c|}
\hline $\begin{array}{l}\text { Studies } \\
\text { 2018-2004 }\end{array}$ & $\begin{array}{l}\text { Theory / model } \\
\text { mentioned }\end{array}$ & $\begin{array}{l}\text { Strength of } \\
\text { theoretical use }\end{array}$ & $\begin{array}{l}\text { Intervention } \\
\text { Treatments }\end{array}$ & $\begin{array}{c}\text { Reported } \\
\text { Behaviour Change } \\
\text { Techniques }\end{array}$ & $\begin{array}{l}\text { Digital Delivery } \\
\text { Features }\end{array}$ & WL Observed & Treatment Differences \\
\hline \multirow[t]{2}{*}{$\begin{array}{l}\text { Brindal et al., } \\
2018 \\
\text { JMIR }\end{array}$} & \multirow[t]{2}{*}{$\begin{array}{l}\text { Theory of Planned } \\
\text { Behavior }\end{array}$} & \multirow[t]{2}{*}{13} & Supportive App & $\begin{array}{l}\text { Information } \\
\text { Goal setting } \\
\text { Prompts } \\
\text { Rewards } \\
\text { Self-monitoring } \\
\text { Feedback }\end{array}$ & $\begin{array}{l}\text { Digital } \\
\text { Smartphone } \\
\text { App (with } \\
\text { gamification) }\end{array}$ & YES & No difference \\
\hline & & & Static App & Information & $\begin{array}{c}\text { Digital } \\
\text { Smartphone } \\
\text { App }\end{array}$ & YES & No difference \\
\hline \multirow[t]{4}{*}{$\begin{array}{l}\text { Hurkmans et al., } \\
2018 \\
\text { JMIR }\end{array}$} & \multirow[t]{4}{*}{$\begin{array}{l}\text { No theory } \\
\text { mentioned }\end{array}$} & \multirow[t]{4}{*}{5} & App & $\begin{array}{l}\text { Information } \\
\text { Goal setting } \\
\text { Self-monitoring } \\
\text { Social support } \\
\end{array}$ & $\begin{array}{c}\text { Digital } \\
\text { Smartphone } \\
\text { App }\end{array}$ & YES & $\begin{array}{l}\text { Not different from Conventional } \\
\text { Greater WL than Control }\end{array}$ \\
\hline & & & Conventional & $\begin{array}{l}\text { Information } \\
\text { Action planning/Tasks } \\
\text { Self-monitoring } \\
\text { Feedback } \\
\text { Social support }\end{array}$ & $\begin{array}{c}\text { Not Digital } \\
\text { (in-person) } \\
\text { NIL }\end{array}$ & YES & $\begin{array}{l}\text { Not different from App } \\
\text { Greater WL than Control }\end{array}$ \\
\hline & & & Combined & $\begin{array}{l}\text { Information } \\
\text { Goal setting } \\
\text { Action planning/Tasks } \\
\text { Self-monitoring } \\
\text { Feedback } \\
\text { Social support } \\
\end{array}$ & $\begin{array}{l}\text { Hybrid Digital } \\
\text { (Part in-person) } \\
\text { Smartphone } \\
\text { App }\end{array}$ & YES & $\begin{array}{l}\text { Greater WL than App } \\
\text { Not different from Conventional } \\
\text { Greater WL than Control }\end{array}$ \\
\hline & & & Control & $\mathrm{NIL}$ & NIL & NO & Less WL than treatment groups \\
\hline $\begin{array}{l}\text { Svetkey et al., } \\
2015 \\
\text { Obesity } \\
\text { Lin, Grambov et } \\
\text { al., } 2018 \\
\text { JMIR }\end{array}$ & $\begin{array}{l}\text { Social Cognitive } \\
\text { Theory (SCT) }\end{array}$ & 10 & App & $\begin{array}{l}\text { Information } \\
\text { Goal setting } \\
\text { Action planning/Tasks } \\
\text { Prompts } \\
\text { Self-monitoring } \\
\text { Feedback } \\
\text { Social support }\end{array}$ & $\begin{array}{l}\text { Digital } \\
\text { Smartphone } \\
\text { App }\end{array}$ & YES & $\begin{array}{l}\text { No difference } \\
\text { (24 months) }\end{array}$ \\
\hline
\end{tabular}




\begin{tabular}{|c|c|c|c|c|c|c|c|}
\hline $\begin{array}{c}\text { Studies } \\
\text { 2018-2004 }\end{array}$ & $\begin{array}{l}\text { Theory / model } \\
\text { mentioned }\end{array}$ & $\begin{array}{l}\text { Strength of } \\
\text { theoretical use }\end{array}$ & $\begin{array}{l}\text { Intervention } \\
\text { Treatments }\end{array}$ & $\begin{array}{c}\text { Reported } \\
\text { Behaviour Change } \\
\text { Techniques } \\
\end{array}$ & $\begin{array}{l}\text { Digital Delivery } \\
\text { Features }\end{array}$ & WL Observed & Treatment Differences \\
\hline & & & Coaching & $\begin{array}{l}\text { Information } \\
\text { Goal setting } \\
\text { Action planning/Tasks } \\
\text { Prompts } \\
\text { Self-monitoring } \\
\text { Feedback } \\
\text { Social support } \\
\end{array}$ & $\begin{array}{l}\text { Limited Digital } \\
\text { (in-person with } \\
\text { limited features } \\
\text { App) }\end{array}$ & YES & $\begin{array}{l}\text { No difference } \\
\text { (24 months) }\end{array}$ \\
\hline & & & Control & Information & NIL & YES & $\begin{array}{c}\text { No difference } \\
(24 \text { months) }\end{array}$ \\
\hline \multirow[t]{3}{*}{$\begin{array}{l}\text { Napolitano et al., } \\
2013 \\
\text { Obesity }\end{array}$} & \multirow[t]{3}{*}{$\begin{array}{l}\text { No theory } \\
\text { mentioned }\end{array}$} & \multirow[t]{3}{*}{7} & Facebook & $\begin{array}{l}\text { Information } \\
\text { Social support }\end{array}$ & $\begin{array}{c}\text { Digital } \\
\text { Facebook }\end{array}$ & YES & Not diff to Control \\
\hline & & & Facebook Plus & $\begin{array}{l}\text { Information } \\
\text { Goal setting } \\
\text { Prompts } \\
\text { Self-monitoring } \\
\text { Feedback } \\
\text { Social support } \\
\end{array}$ & $\begin{array}{l}\text { Digital } \\
\text { Facebook + } \\
\text { SMS }\end{array}$ & YES & $\begin{array}{l}\text { Greater WL than } \\
\text { Facebook and Control groups }\end{array}$ \\
\hline & & & Control & $\mathrm{NIL}$ & NIL & NO & Not diff to Facebook \\
\hline \multirow{3}{*}{$\begin{array}{l}\text { Shaw et al., } 2013 \\
\text { Am J Med } \\
\text { Shaw et al., } 2013 \\
\text { JMIR }\end{array}$} & \multirow[t]{3}{*}{$\begin{array}{l}\text { Regulatory Focus } \\
\text { Theory }\end{array}$} & \multirow[t]{3}{*}{22} & Promotion & $\begin{array}{l}\text { Information } \\
\text { Action planning/Tasks } \\
\text { Rewards } \\
\text { Self-monitoring } \\
\end{array}$ & $\begin{array}{c}\text { Digital } \\
\text { SMS (daily) }\end{array}$ & YES & Not different from control (3 months) \\
\hline & & & Prevention & $\begin{array}{l}\text { Information } \\
\text { Action planning/Tasks } \\
\text { Self-monitoring } \\
\end{array}$ & $\begin{array}{c}\text { Digital } \\
\text { SMS (daily) } \\
\end{array}$ & YES & $\begin{array}{l}\text { Greater sustained WL than control } \\
\text { ( } 3 \text { months) } \\
\text { Not different from prevention }\end{array}$ \\
\hline & & & Control & Information & $\begin{array}{c}\text { Digital } \\
\text { SMS (daily) }\end{array}$ & YES & Not different from promotion \\
\hline \multirow[t]{2}{*}{$\begin{array}{l}\text { Shapiro et al., } \\
2012 \\
\text { Prev Med }\end{array}$} & \multirow[t]{2}{*}{$\begin{array}{l}\text { Social Cognitive } \\
\text { Theory (SCT) }\end{array}$} & \multirow[t]{2}{*}{10} & SMS & $\begin{array}{l}\text { Information } \\
\text { Goal setting } \\
\text { Action planning/Tasks } \\
\text { Prompts } \\
\text { Self-monitoring }\end{array}$ & $\begin{array}{c}\text { Digital } \\
\text { SMS/MMS } \\
+ \\
\text { website } \\
\end{array}$ & YES & No difference \\
\hline & & & Control & Information & $\begin{array}{l}\text { Digital } \\
\text { Email }\end{array}$ & YES & No difference \\
\hline
\end{tabular}




\begin{tabular}{|c|c|c|c|c|c|c|c|}
\hline $\begin{array}{c}\text { Studies } \\
2018-2004\end{array}$ & $\begin{array}{l}\text { Theory / model } \\
\text { mentioned }\end{array}$ & $\begin{array}{c}\text { Strength of } \\
\text { theoretical use }\end{array}$ & $\begin{array}{l}\text { Intervention } \\
\text { Treatments }\end{array}$ & $\begin{array}{c}\text { Reported } \\
\text { Behaviour Change } \\
\text { Techniques } \\
\end{array}$ & $\begin{array}{l}\text { Digital Delivery } \\
\text { Features }\end{array}$ & WL Observed & Treatment Differences \\
\hline \multirow[t]{3}{*}{$\begin{array}{l}\text { Burke et al., } 2011 \\
\text { Am J Prev Med }\end{array}$} & \multirow[t]{3}{*}{$\begin{array}{l}\text { Social Cognitive } \\
\text { Theory (SCT) } \\
\text { Self-regulation } \\
\text { model }\end{array}$} & \multirow[t]{3}{*}{11} & PDA & $\begin{array}{l}\text { Information } \\
\text { Goal setting } \\
\text { Self-monitoring } \\
\text { Feedback }\end{array}$ & $\begin{array}{c}\text { Digital } \\
\text { PDA } \\
\text { (self-monitoring } \\
\text { software) } \\
\end{array}$ & YES & No difference \\
\hline & & & PDA Plus & $\begin{array}{l}\text { Information } \\
\text { Goal setting } \\
\text { Self-monitoring } \\
\text { Feedback (tailored) }\end{array}$ & $\begin{array}{c}\text { Digital } \\
\text { PDA } \\
\text { (self-monitoring } \\
\text { software) } \\
\end{array}$ & YES & No difference \\
\hline & & & Paper & $\begin{array}{l}\text { Information } \\
\text { Goal setting } \\
\text { Self-monitoring } \\
\text { Feedback } \\
\text { Social support }\end{array}$ & $\begin{array}{l}\text { Not Digital } \\
\text { (in-person) }\end{array}$ & YES & No difference \\
\hline \multirow[t]{2}{*}{$\begin{array}{l}\text { Turner-McGrievy } \\
\text { and Tate, } 2011 \\
\text { JMIR }\end{array}$} & \multirow[t]{2}{*}{$\begin{array}{l}\text { Social Cognitive } \\
\text { Theory (SCT) }\end{array}$} & \multirow[t]{2}{*}{13} & Podcast & $\begin{array}{l}\text { Information } \\
\text { Self-monitoring (paper) }\end{array}$ & $\begin{array}{c}\text { Digital } \\
\text { Podcast website } \\
\end{array}$ & YES & No difference \\
\hline & & & Podcast + App & $\begin{array}{l}\text { Information } \\
\text { Self-monitoring (app) } \\
\text { Social support }\end{array}$ & $\begin{array}{c}\text { Digital } \\
\text { Podcast website + } \\
\text { App } \\
+ \\
\text { Twitter } \\
\end{array}$ & YES & No difference \\
\hline \multirow[t]{2}{*}{$\begin{array}{l}\text { Lee W, et al., } \\
2010 \\
\text { J Telemed } \\
\text { Telecare }\end{array}$} & \multirow[t]{2}{*}{$\begin{array}{l}\text { No theory } \\
\text { mentioned }\end{array}$} & \multirow[t]{2}{*}{2} & Gamification & $\begin{array}{l}\text { Information } \\
\text { Self-monitoring }\end{array}$ & $\begin{array}{c}\text { Digital } \\
\text { Smartphone } \\
\text { App (with } \\
\text { gamification) } \\
\end{array}$ & YES & More WL than Control \\
\hline & & & Control & NIL & NIL & NO & Less WL than Gamification \\
\hline \multirow[t]{2}{*}{$\begin{array}{l}\text { Harvey-Berino et } \\
\text { al., } 2010 \\
\text { Prev Med }\end{array}$} & \multirow[t]{2}{*}{$\begin{array}{l}\text { No theory } \\
\text { mentioned }\end{array}$} & \multirow[t]{2}{*}{10} & Internet & $\begin{array}{l}\text { Information } \\
\text { Self-monitoring } \\
\text { Social support }\end{array}$ & Website & YES & $\begin{array}{l}\text { Less WL than In-person } \\
\text { Not different from hybrid group }\end{array}$ \\
\hline & & & In-person & $\begin{array}{l}\text { Information } \\
\text { Self-monitoring } \\
\text { Social support }\end{array}$ & $\begin{array}{l}\text { Not Digital } \\
\text { (in-person) }\end{array}$ & YES & $\begin{array}{l}\text { More WL than Internet } \\
\text { or hybrid groups }\end{array}$ \\
\hline
\end{tabular}




\begin{tabular}{|c|c|c|c|c|c|c|c|}
\hline $\begin{array}{c}\text { Studies } \\
\text { 2018-2004 }\end{array}$ & $\begin{array}{l}\text { Theory / model } \\
\text { mentioned }\end{array}$ & $\begin{array}{l}\text { Strength of } \\
\text { theoretical use }\end{array}$ & $\begin{array}{l}\text { Intervention } \\
\text { Treatments }\end{array}$ & $\begin{array}{c}\text { Reported } \\
\text { Behaviour Change } \\
\text { Techniques } \\
\end{array}$ & $\begin{array}{c}\text { Digital Delivery } \\
\text { Features }\end{array}$ & WL Observed & Treatment Differences \\
\hline & & & Hybrid & $\begin{array}{l}\text { Information } \\
\text { Self-monitoring } \\
\text { Social support }\end{array}$ & $\begin{array}{l}\text { Hybrid Digital } \\
\text { (Part in-person) } \\
\text { Website }\end{array}$ & YES & $\begin{array}{l}\text { Less WL than In-person } \\
\text { Not different from Internet group }\end{array}$ \\
\hline \multirow[t]{2}{*}{$\begin{array}{l}\text { Haapala et al., } \\
2009 \\
\text { Public Health } \\
\text { Nutr }\end{array}$} & \multirow[t]{2}{*}{$\begin{array}{l}\text { Systems } \\
\text { contingency } \\
\text { approach } \\
\text { Self-efficacy } \\
\text { theory }\end{array}$} & \multirow[t]{2}{*}{16} & Intervention & $\begin{array}{l}\text { Information } \\
\text { Prompts } \\
\text { Self-monitoring } \\
\text { Feedback }\end{array}$ & $\begin{array}{c}\text { Digital } \\
\text { SMS } \\
+ \\
\text { website } \\
\end{array}$ & YES & Greater WL than control \\
\hline & & & Control & NIL & $\mathrm{NIL}$ & YES & Less WL than Intervention \\
\hline \multirow[t]{2}{*}{$\begin{array}{l}\text { Patrick et al., } \\
2009 \\
\text { J Med Internet } \\
\text { Res }\end{array}$} & \multirow[t]{2}{*}{$\begin{array}{l}\text { No theory } \\
\text { mentioned }\end{array}$} & \multirow[t]{2}{*}{10} & Intervention & $\begin{array}{l}\text { Information } \\
\text { Goal setting } \\
\text { Action planning/Tasks } \\
\text { Prompts } \\
\text { Self-monitoring } \\
\text { Feedback } \\
\end{array}$ & $\begin{array}{l}\text { Digital } \\
\text { SMS }\end{array}$ & YES & Greater WL than comparison \\
\hline & & & Comparison & Information & $\mathrm{NIL}$ & YES & Less WL than Intervention \\
\hline \multirow[t]{2}{*}{$\begin{array}{l}\text { Gold et al., } 2007 \\
\text { Obesity }\end{array}$} & \multirow[t]{2}{*}{$\begin{array}{l}\text { No theory } \\
\text { mentioned }\end{array}$} & \multirow[t]{2}{*}{9} & Vtrim & $\begin{array}{l}\text { Information } \\
\text { Action planning/Tasks } \\
\text { Self-monitoring } \\
\text { Feedback } \\
\text { Social support }\end{array}$ & $\begin{array}{c}\text { Digital } \\
\text { Website }\end{array}$ & YES & Greater WL than eDiets \\
\hline & & & eDiets.com & $\begin{array}{l}\text { Information } \\
\text { Goal setting } \\
\text { Self-monitoring } \\
\text { Feedback } \\
\text { Social support }\end{array}$ & $\begin{array}{l}\text { Digital } \\
\text { Website }\end{array}$ & YES & Less WL than VTrim \\
\hline \multirow[t]{2}{*}{$\begin{array}{l}\text { Tate et al., } 2006 \\
\text { Arch Int Med }\end{array}$} & \multirow[t]{2}{*}{$\begin{array}{l}\text { Cognitive- } \\
\text { behavioral theory }\end{array}$} & \multirow[t]{2}{*}{12} & $\begin{array}{l}\text { HC (Human } \\
\text { counselling) }\end{array}$ & $\begin{array}{l}\text { Information } \\
\text { Self-monitoring } \\
\text { Feedback (counsellor) } \\
\text { Social support }\end{array}$ & $\begin{array}{c}\text { Hybrid Digital } \\
\text { (part in-person) } \\
\text { Website } \\
\text { + e-mail } \\
\end{array}$ & YES & $\begin{array}{c}\text { Greater WL than Control ( } 3 \text { mths) } \\
\text { Greater WL than Control ( } 6 \text { mths) } \\
\text { Not different to AC (3mths) } \\
\text { Greater WL than AC (6 mths) }\end{array}$ \\
\hline & & & $\begin{array}{l}\text { AC (Automated } \\
\text { counselling) }\end{array}$ & $\begin{array}{l}\text { Information } \\
\text { Self-monitoring } \\
\text { Feedback (automated) } \\
\text { Social support }\end{array}$ & $\begin{array}{c}\text { Digital } \\
\text { Website }\end{array}$ & YES & $\begin{array}{c}\text { Greater WL than Control ( } 3 \text { mths) } \\
\text { Not different to Control (6 mths) } \\
\text { Not different to HC ( } 3 \mathrm{mths}) \\
\text { Less WL than HC (6 mths) }\end{array}$ \\
\hline
\end{tabular}




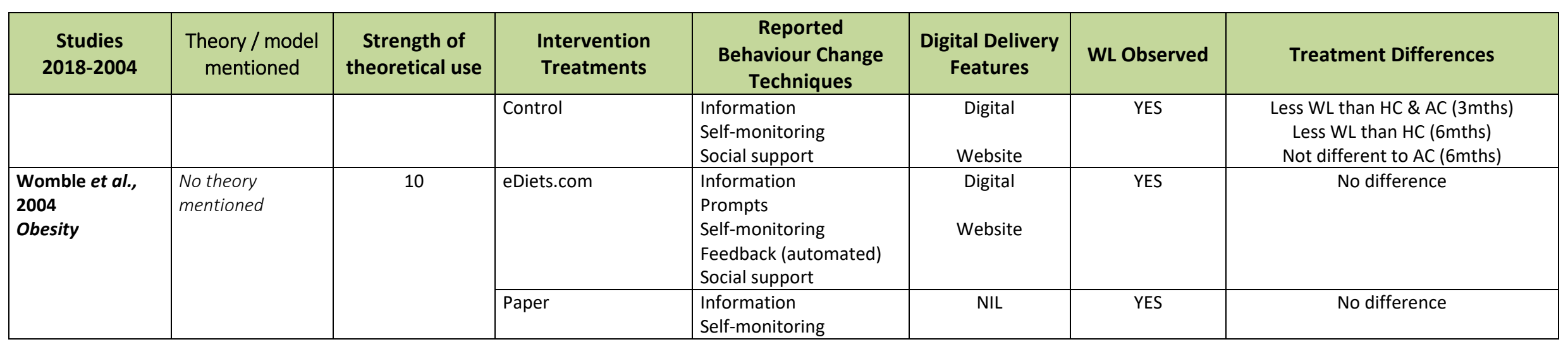

